\title{
Biogenic nanoparticles: a comprehensive perspective in synthesis, characterization, application and its challenges
}

\author{
Sunita Patil ${ }^{1,2}$ and Rajkuberan Chandrasekaran ${ }^{3^{*}}$ (D)
}

\begin{abstract}
Background: Translating the conventional scientific concepts into a new robust invention is a much needed one at a present scenario to develop some novel materials with intriguing properties. Particles in nanoscale exhibit superior activity than their bulk counterpart. This unique feature is intensively utilized in physical, chemical, and biological sectors. Each metal is holding unique optical properties that can be utilized to synthesize metallic nanoparticles. At present, versatile nanoparticles were synthesized through chemical and biological methods.

Main body of abstract: Metallic nanoparticles pose numerous scientific merits and have promising industrial applications. But concerning the pros and cons of metallic nanoparticle synthesis methods, researchers elevate to drive the synthesis process of nanoparticles through the utilization of plant resources as a substitute for use of chemicals and reagents under the theme of green chemistry. These synthesized nanoparticles exhibit superior antimicrobial, anticancer, larvicidal, leishmaniasis, wound healing, antioxidant, and as a sensor. Therefore, the utilization of such conceptualized nanoparticles in treating infectious and environmental applications is a warranted one.

Conclusion: Green chemistry is a keen prudence method, in which bioresources is used as a template for the synthesis of nanoparticles. Therefore, in this review, we exclusively update the context of plant-based metallic nanoparticle synthesis, characterization, and applications in detailed coverage. Hopefully, our review will be modernizing the recent trends going on in metallic nanoparticles synthesis for the blooming research fraternities.
\end{abstract}

Keywords: Metallic nanoparticles, Gold, Silver, Antimicrobial, Anticancer, Iron oxide

\section{Highlights}

$>$ Metallic nanoparticles are a new dimensional form of nanoparticles possessing splendid optical properties.

$>$ The synthesis of metallic nanoparticles from plants and its parts is a time deed one.

$>$ The characterizations of nanoparticles infer the nano shape and size of the nanoparticles.

$>$ Application of nanoparticles in diseases management and environmental sector is emphasized in prolific manner.

\footnotetext{
* Correspondence: kuberan87@gmail.com

${ }^{3}$ Department of Biotechnology, Karpagam Academy of Higher Education,

Coimbatore, India

Full list of author information is available at the end of the article
}

$>$ Challenges in green synthesis should be resolved and the feasibility of green synthesized nanoparticles in translating into industrial applications must be focused for future medicine.

\section{Background}

Nanotechnology is a new-fangled term that becomes an inescapable part of the modern tool and people are now witnessing the ease of technology in day to day applications [1]. The small-sized nanoparticles $(1-100 \mathrm{~nm})$ dominate the entire research globally, due to its stupendous applications in physical, chemical, and biological sciences [2]. Due to intensive and extensive research by the research fraternity, nanotechnology has successfully

\section{Springer Open}

(c) The Author(s). 2020 Open Access This article is licensed under a Creative Commons Attribution 4.0 International License, which permits use, sharing, adaptation, distribution and reproduction in any medium or format, as long as you give appropriate credit to the original author(s) and the source, provide a link to the Creative Commons licence, and indicate if changes were made. The images or other third party material in this article are included in the article's Creative Commons licence, unless indicated otherwise in a credit line to the material. If material is not included in the article's Creative Commons licence and your intended use is not permitted by statutory regulation or exceeds the permitted use, you will need to obtain permission directly from the copyright holder. To view a copy of this licence, visit http://creativecommons.org/licenses/by/4.0/. 
knocked on the door and a common man at present scenario experiencing the feature of nanotechnology [3].

The delivery address given by Nobel laureate Richard P. Feynman "There's Plenty of Room at the Bottom" received colossal attention from researchers and there onwards nanotechnology steps ahead and make various revolutionary developments in the field of nanotechnology [4]. When materials are operated at the nanoscale level, the properties of the materials have changed and exhibited tremendous optical, magnetic, and electrical properties. Such kind of unique nano properties is utilized in electronics, batteries, fuel additives, solar cells, catalysts, electrochemical industries, defense, cosmetics, pharmaceuticals, food additives and packaging, agriculture, biosensors, diagnostic imaging, vaccines, antimicrobial and chemotherapy, and drug delivery [5].

Nanoparticles (NP's) play a decisive role in developing various dimensions of nanomaterials such as carbon nanotubes $(\mathrm{CN})$, metal nanoparticles $(\mathrm{MN})$, ceramic nanoparticles $(\mathrm{CN})$, semiconductor nanoparticles $(\mathrm{SN})$, and polymeric and lipid-based nanoparticles [6]. These kinds of nanoparticles are varying in their morphology, size and shape, and optical properties but excel in various applications in divergent fields [7].

In this review, we conceptualize the green synthesis of metal nanoparticles (MN) synthesis (plants only), characterization, and their biological applications in a lucid approach. Further, we brief the technical challenges of nanoparticles synthesis and its obstacles, toxicity and environmental concern of MN's, and its perspective for commercialization of MN's. For the past few decades, numerous reports have been published in view of MN's synthesis; but addressing the challenges and its associated problems of MNs is very limited. Due to this rationale, we intend to provide a comprehensive review of MN's. This review will pose a better understanding of the biosynthesis of nanoparticles (NPs) and their applications to the scientific community in a substantial manner.

\section{Main text}

\section{Traditional nano concepts and its applications}

Nanotechnology is not an era of modern science while reverting to history; nanotechnology exists in the history of arts and nature beings. In sculpture, gold and copper are mixed with other substances and reduced in a defined temperature into respective metal ions. This resultant mixture is applied on the surface of the coatings to make a glittering effect. Naturally, NP operates at the nanoscale in various living beings. These natural nanomaterials have the unique property of molecular recognition due to which they can self assemble [8]. The most dynamic example of natural nanoparticles is a nanoscopic wax crystal papillae in the upper side of each epidermal cell of lotus leaf to reduce the contact area of water with leaf. As a result, its scientific basis has opened the possibilities of fabricating superhydrophobic surfaces for a variety of products such as Lotusan ${ }^{\circ}$ a selfcleaning paint (lotus effect), slippery liquid-infused porous surface (SLIPS) used in refrigeration (nepenthes walls). Bhasma is a unique Ayurvedic herbal-mineralmetallic compound in the size of nano dimensions (usually 5-50 nm). These are the products of classical Indian alchemy, the "Ayurveda Rasa Shastra," used for treating diverse chronic ailments.

In the current epoch, nano-based concepts and applications are again flourishing since the 1990s in all scientific sectors. In particular, the Nanobiotechnology concept started at the beginning of the twentieth century exploring various new avenues in the development of nanomedicine and for developing a sustainable environment.

\section{Metallic nanoparticles}

Metallic nanoparticles are becoming the limelight of research for scientists and they have proved their competence in various reports addressing the synthesis and applications of versatile inorganic metal nanoparticles (silver, gold, copper, iron, gold, platinum, and palladium) [9] (Fig. 1). The specific properties of metallic nanoparticles are it exhibits prospective optoelectronic and dimensional characteristics superior to their bulk metals [10]. These particular traits render an increase in the surface to volume ratio, reactivity, efficiency, and functional modifications that can tap their potential in diverse applications as multifunctional technical tools [11].

\section{Nanoparticles synthesis}

\section{Approaches of nanoparticles synthesis}

For fabrication NP's with the desired shape and size, strikingly there are two classical approaches based on their assemblies followed, either they are top-down and bottom-up approach [12] (Fig. 2). Both these approaches differ in the synthesis principles but finally produce NPs with desired characteristics. In the top-down approach,

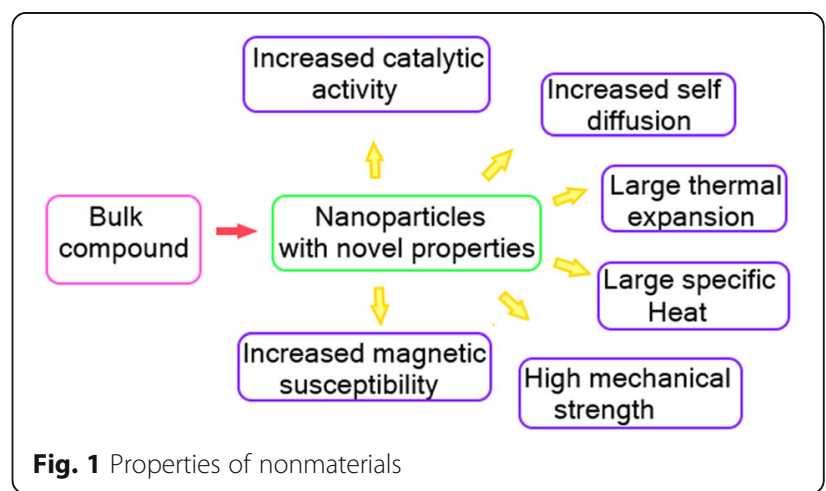




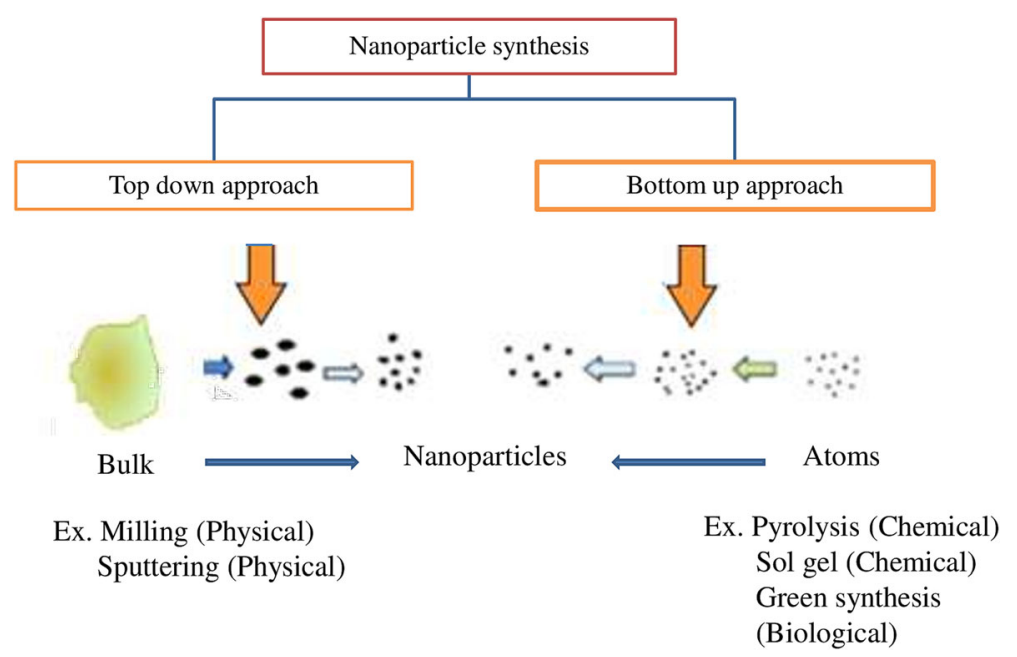

Fig. 2 Approaches of nanoparticles synthesis

bulk materials were shattered into the bit to bit pieces leading to the fine generations of NPs. Such kind of NP's production methods were accomplished by photolithographic techniques, grinding, sputtering, and milling [13]. Each method has its limitations and fine production capacity of NPs. The top-down approach is quite a feasible technique resulting in the production of a large mass of NPs. But the disadvantages associated with topdown are surface imperfection of NPs and in some cases, NP's may get damaged [14]. The optical and physiochemical properties of the NPs depend on the surface architecture of NPs; henceforth, top-down approach of NPs synthesis is restricted in some cases of applications.

Another fashionable approach, for NPs production, is the bottom-up approach by coalescence or assembling of atoms by atoms, molecules by molecules, cluster by cluster to generate a diverse range of NP's [15]. Techniques like self-assembly of monomer/polymer molecules, chemical or electrochemical nanostructural precipitation, sol-gel processing, laser pyrolysis, chemical vapor deposition (CVD), plasma or flame spraying synthesis, and bio-assisted synthesis are employed for the production of NPs [16]. Henceforth, bottom-up is an amenable technique for creating nanoclusters intended for various applications.

\section{Methods of nanoparticles synthesis Physical methods of nanoparticles synthesis}

The synthesis of nanomaterials using physical methods involves deposition, sputtering, ball milling, and plasmabased techniques [16]. The rate of synthesis of metal nanoparticles is very slow in most of these methods. For example, a yield of nanomaterials is $50 \%$ or less for ball milling techniques [17]. In the case of sputtering, a big particle size distribution is obtained and only $6-8 \%$ of sputtered material is reported to be less than $100 \mathrm{~nm}$. A high-energy consumption is required for laser ablation and plasma techniques. Extensive size distribution, slow production rate, and waste by-products and high consumption of energy make most of the physical methods extremely expensive which cannot be adopted for practical commercial applications [18].

\section{Chemical-mediated synthesis of nanoparticles}

A variety of chemical methods for nanoparticle synthesis has been put forward and most of them are widely used to synthesize nanostructured materials (e.g., chemical reduction, pyrolysis, sol-gel method, microemulsion, polyol synthesis, hydrothermal synthesis, chemical vapor deposition) [19]. Moreover, employing hazardous chemicals and reagents during the synthesis process and generation of byproducts is lethal to humans and the environment also [20]. Therefore, specifically such kind of NPs is limited for biological applications.

\section{Biological-mediated synthesis of nanoparticles}

Green nanotechnology is an emerging field to design novel NPs using a green chemistry approach. Biological methods of NPs synthesis provide a new possibility of synthesizing NPs using natural reducing and stabilizing agents. It is an economical and environmentally friendly alternative to chemical and physical approaches with no usage of energy and toxic chemicals.

Biological synthesis of NPs is a bottom-up approach that involves the use of simple unicellular to complex multicellular biological entities like bacteria, fungi, actinomycetes and yeast, algae, and plant materials [21-27]. Microbial-mediated synthesis of nanoparticles is another 
variant method of producing nanoparticles. In this synthesis method, microbial culture filtrates (extracellular and intracellular) are used as a reducing agent for nanoparticles production. Generically, microbes like bacteria, fungi, yeast, and actinomycetes having the metal-tolerant capability and thrive at utmost environmental conditions [28]. These inherent features are employed by microbes to tolerate, accumulate, and convert metal into respective metal ions. For instance, the first bacterial gold nanoparticles were synthesized from Bacillus subtilis [29]. Likewise, the variant face of metallic nanoparticles silver, gold, copper, iron, zinc, platinum, and selenium were synthesized from the bacterium. The common phenomenon in reducing metals into metal ions is by redox reactions through the intracellular/extracellular pathway. At first, the metal is trapped onto the surface of bacterial cells while later, these trapped metals were exclusively reduced into metal ions by the action of enzyme $\mathrm{NADH}$ and $\mathrm{NADH}$-dependent nitrate reductase enzymes [30]. These enzymes perform electron shuttle donor processes during synthesizing nanoparticles which are reported in the synthesis of silver nanoparticles from Bacillus licheniformis [31].

In fungi, Fusarium oxysporum synthesized silver nanoparticles by the action of nitrate reductase and anthraquinones [32]. Conceivably, with the above bacterialand fungal-mediated synthesis of metallic nanoparticles, it is evident that NADPH nitrate reductase is a major biofactor in the synthesis of metallic nanoparticles.

Though green nanoparticles are a new alternative method for conventional nanoparticles synthesis, but for a nanoparticles synthesis and production, an ease method should be adopted. In-universe, amply bioresources (plants, microbes) were available. But for synthesis and commercialization perspective, utilization of such bioresources is imperative. In such a case, microbes can be effectively utilized; expensive, but the handling of microbes, scale-up process, molecular mutation, hurdles in mass cultivation, downstream processing, and other factors make a bottleneck for nanoparticles synthesis and application. Henceforth, research should drive lucidly; employing plants as a resource in nanoparticles synthesis is indeed one. Plants bestowed with numerous active constituents phenols, alkaloids, flavonoids, terpenoids, saponins, tannins, polysaccharides, polyphenols vitamins, etc. These constituents were effectively reduced and stabilized the nanoparticles. Moreover, using plants as a resource for synthesis offers advantages such as plant material availability, cost inexpensive, easy scalable for mass production, secondary metabolites, and purgative properties. Proper and optimized use of biological entities for the synthesis of NPs will produce well-characterized and highly stable NPs.
Schematically, a generic equation for the NPs synthesis is as follows:

$$
A+B \underset{{ }^{\circ} C, T, R P M, p H}{\stackrel{\Delta}{\rightarrow}} C+D \text { (Fig. 3a, b) }
$$

$A$ denote plant moieties; $B$ denote chemical precursors [salts].

When $A$ reacted with $B$ [salt] in the presence of heat, temperature, rotation per minute [RPM], and $\mathrm{pH}, A$ reduce $B$ into respective metal ions and byproducts. The rate of reduction and generation of NPs is influenced by various factors such as time, temperature, stiochemistric proportion, and $\mathrm{pH}$. The synthesis of metallic nanoparticles is accountable by the action of phytoconstituents present in the plant extracts. Plants endowed with numerous active constituents; these constituents activate the reaction mechanism and synthesize the metallic nanoparticles. Similarly, the synthesis of metallic oxide nanoparticles is the same process but until now a lucid mechanism is not yet been explored [33].

\section{Technical challenges for nanoparticles synthesis}

Generally, the production of NPs with a specific shape, size, and distribution can be achieved by changing the methods of synthesis, the reducing agents, and stabilizers [34]. The data from Table 1 showed how plant extract greatly affects the size and shape of NPs. There are variations in plant extract used and the methodology adopted for the synthesis is important to standardize and optimize the synthesis protocol to get NPs with desired size, shape, and surface charges.

Likewise, the synthesis of NPs using the same plant material showed variation in its characters due to differences in the synthesis method. Table 2 shows a synthesis of metal NPs using Zingiber officinale rhizome extract. The researcher used different methods for the preparation of extract, different concentration of precursor, and reducing agent with various temperature and $\mathrm{pH}$. The NPs obtained with these methods are having different features concerning size and shape.

In aspects of large-scale synthesis, among the plant materials, leaves can be extensively used for largescale synthesis. The plant material (leaves) will be available at all times and all seasons. Moreover, the plants will not be affected by using leaves but using other resources like a flower, fruit, seed, root, and latex will also be meaningful but the volume of materials and it should not affect crop productivity. Moreover, the plant-based nanoparticles are reproducible, stable, and environmentally friendly also. In plantmediated nanoparticles, various parameters like $\mathrm{pH}$, 


\section{a}
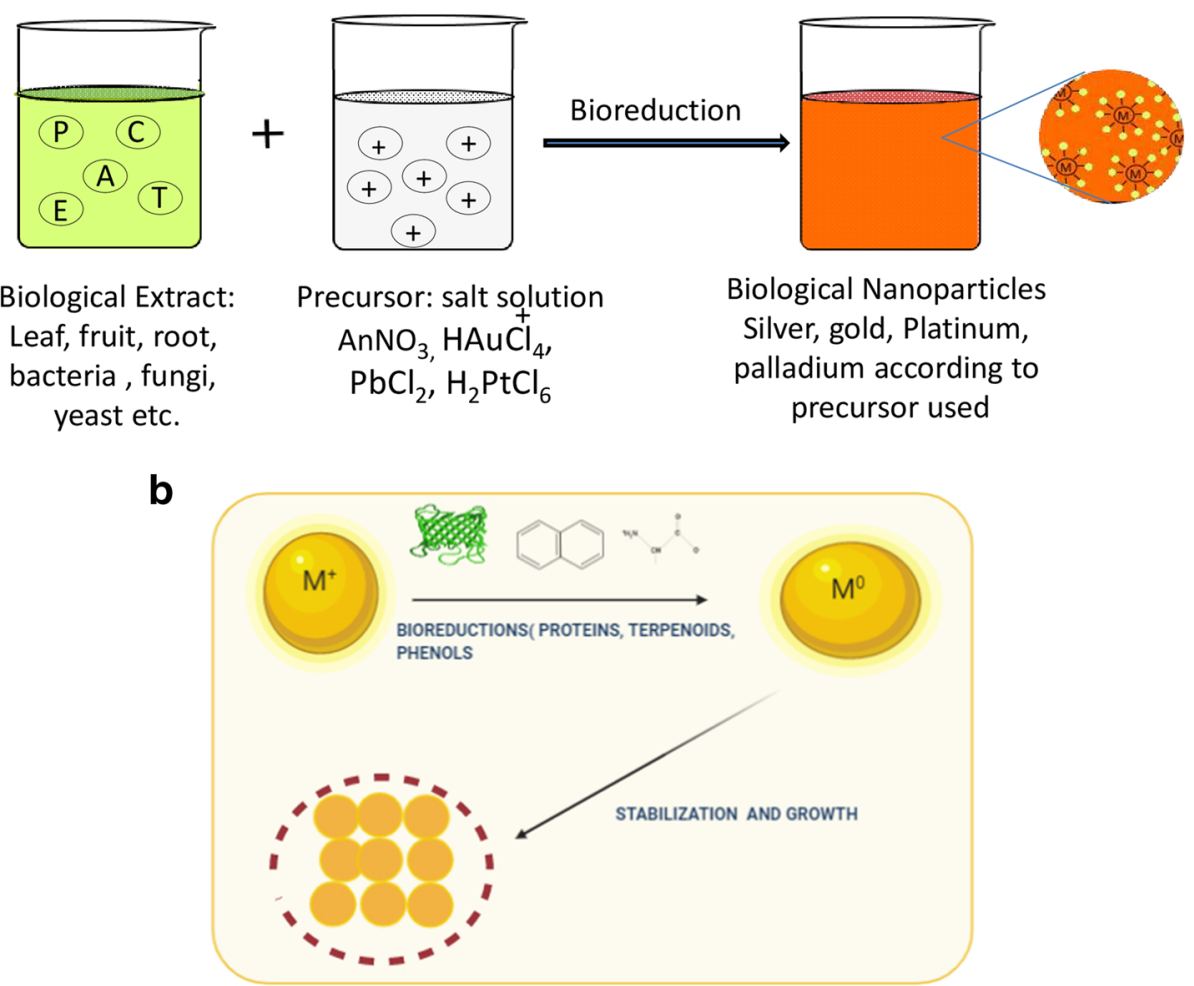

Fig. 3 a Biological synthesis of nanoparticles. b Mechanism of plant-mediated metallic nanoparticles synthesis

precursor, and extract concentration, time, and other factors will determine the size of nanoparticles. Since plant constituents were different in species and genera level, so optimization of these parameters will eventually produce nanoparticles with the desired size and shape. Another important concern of nanoparticles is stability. The colloidal stability of nanoparticles is important for long-term application studies. Comparatively, chemical-mediated synthesis of nanoparticles is stable for a long duration; biological synthesis of nanoparticles stability is determined by the capping agents. In a study, silver nanoparticles are synthesized chemically and biologically; the zeta potential of chemical AgNPs is $17.8 \mathrm{mV}$ and biological AgNPs are $15.2 \mathrm{mV}$ [75]. In biological nanoparticles, the stability of the nanoparticles solution is due to the stabilization of the metal particles by the biomolecules. Moreover, the stability of the nanoparticles is determined by $\mathrm{pH}$, surface capping agents, and functionalization techniques.

\section{Effect of $\mathrm{pH}$}

The role of $\mathrm{pH}$ during nanoparticle synthesis not only affects size but also the shape of the particle. Yang and Li [76] demonstrated the shape of the product prepared under lower $\mathrm{pH}$ was less regular and tend to aggregate. While synthesis of NPs under different $\mathrm{pH}$ conditions, the size of particles can be produced with the desired size and shape uniformly [77-79]. The $\mathrm{pH}$ causes the local surface of nanoparticles by protonation and deprotonation of molecular atoms in the nucleation and growth stage of NPs [80]. At the alkaline $\mathrm{pH}$ range, the NPs forms cluster distribution in the colloidal stage preventing aggregation [81]. Armendari et al. [36] demonstrated the role of $\mathrm{pH}$ in gold nanoparticles synthesis and as a result, the synthesized nanoparticles exhibit tetrahedral, decahedral, hexagonal, icosahedral multitwinned, irregular, and rod shape at $\mathrm{pH}$ values of 2,3 , and 4. Therefore, formations of truncated octahedron, rhomb-dodecahedron, cubic, octahedron, and octagon structures are thermodynamically favored at the nucleation stage and at the initial growth stage when the particle sizes are not very large [48].

\section{Effect of precursor and reducing agents concentration}

The concentration of reactants like precursors and reducing agents also affect the size of NPs formed. This phenomenon may be due to too many reducing agents bound to the surface of preformed nuclei, which intensifies the secondary reduction of silver ions on the surface of the nuclei. Consequently, the growth rate of NPs is 
Table 1 Effect of biological material, precursor concentration and extract concentration on the morphology of biological nanoparticles

\begin{tabular}{|c|c|c|c|c|c|c|}
\hline $\begin{array}{l}\text { Plant name and } \\
\text { part used }\end{array}$ & Nanoparticles & Precursor & $\begin{array}{l}\text { Concentration of } \\
\text { plant extract used }\end{array}$ & Size & Shape & References \\
\hline Aloe vera leaf & $\begin{array}{l}\text { Gold and } \\
\text { Silver }\end{array}$ & $\begin{array}{l}1 \mathrm{mM} \\
\mathrm{HAuCl}_{4} \\
10 \mathrm{mM} \\
\mathrm{AgNO}_{3}\end{array}$ & $\begin{array}{l}0.5-4 \mathrm{~mL} \\
5 \mathrm{~mL}\end{array}$ & $5-50 \mathrm{~nm}$ & Gold-triangular, spherical Silver-spherical & [35] \\
\hline $\begin{array}{l}\text { Avena sativa } \\
\text { biomass }\end{array}$ & Gold & $\begin{array}{l}0.1 \mathrm{mM} \\
\mathrm{Au}(I I I)\end{array}$ & $2 \mathrm{~mL}$ & $5-20 \mathrm{~nm}$ & $\begin{array}{l}\text { Tetrahedral, deca- hedral, hexagonal, } \\
\text { icosahedral multitwinned, irregular shape, } \\
\text { and rod shape nanoparticles }\end{array}$ & [36] \\
\hline $\begin{array}{l}\text { Black tea leaf } \\
\text { extract }\end{array}$ & $\begin{array}{l}\text { Gold and } \\
\text { Silver }\end{array}$ & $\begin{array}{l}0.01 \mathrm{M} \\
\mathrm{HAuCl}_{4} \\
\mathrm{AgNO}_{3}\end{array}$ & $10 \mathrm{~mL}$ & 20 & spherical & [37] \\
\hline $\begin{array}{l}\text { Cinnamon } \\
\text { zeylanicum bark } \\
\text { powder }\end{array}$ & Silver & $\begin{array}{l}1 \mathrm{mM} \\
\mathrm{AgNO}_{3}\end{array}$ & $5 \mathrm{~mL}$ & $31-40$ & cubic, hexagonal & [38] \\
\hline $\begin{array}{l}\text { Hibiscus rosa } \\
\text { sinensis leaf }\end{array}$ & Gold, Silver & $\begin{array}{l}0.0005 \mathrm{M} \\
\mathrm{HAuCl}_{4} \\
0.0008 \mathrm{M} \\
\mathrm{AgNO}_{3}\end{array}$ & $\begin{array}{l}5 \mathrm{~mL} \\
20 \mathrm{~mL}\end{array}$ & $\begin{array}{l}14 \\
13\end{array}$ & $\begin{array}{l}\text { Gold-triangular, hexagonal, dodecahedral } \\
\text { and spherical } \\
\text { Silver-spherical }\end{array}$ & [39] \\
\hline $\begin{array}{l}\text { Ocimum sanctum } \\
\text { leaf }\end{array}$ & Gold, Silver & $\begin{array}{l}1 \mathrm{mM} \\
\mathrm{AuCl}_{4} \\
1 \mathrm{mM} \\
\mathrm{AgNO}_{3}\end{array}$ & $\begin{array}{l}30 \mathrm{~mL} \\
25 \mathrm{~mL}\end{array}$ & $\begin{array}{l}30 \\
13\end{array}$ & $\begin{array}{l}\text { Gold-hexagonal, prism } \\
\text { Silver-spherical }\end{array}$ & [40] \\
\hline $\begin{array}{l}\text { Parthenium } \\
\text { hysterophorus leaf }\end{array}$ & Silver & $\begin{array}{l}1 \mathrm{mM}^{\mathrm{M}} \\
\mathrm{AgNO}_{3}\end{array}$ & $50 \mathrm{~mL}$ & 50 & Irregular & [41] \\
\hline Pear fruit extract & Gold & $\begin{array}{l}2 \mathrm{mM} \\
\mathrm{HAuCl}_{4}\end{array}$ & $500 \mathrm{~mL}$ & $200-500$ & Triangular, hexagonal & [42] \\
\hline $\begin{array}{l}\text { Tamarindus indica } \\
\text { leaf }\end{array}$ & Gold & $\begin{array}{l}1 \mathrm{mM} \\
\mathrm{HAuCl}_{4}\end{array}$ & $45 \mathrm{~mL}$ & $20-40$ & triangular & [43] \\
\hline $\begin{array}{l}\text { Garcinia } \\
\text { mangostana } \\
\text { pericarp }\end{array}$ & Gold, Silver & $\begin{array}{l}10 \mathrm{mM}_{1} \\
\mathrm{HAuCl}_{4} \\
10 \mathrm{mM}_{1} \\
\mathrm{AgNO}_{3}\end{array}$ & $3 \mathrm{~mL}$ & $\begin{array}{l}13.65 \pm 5.07 \text { to } \\
31.08 \pm 3.99\end{array}$ & Nanodumbbell shapes & [44] \\
\hline $\begin{array}{l}\text { Terminalia chebula } \\
\text { Seed }\end{array}$ & Gold & $\begin{array}{l}0.01 \mathrm{M} \\
\mathrm{HAuCl}_{4}\end{array}$ & $2 \mathrm{~mL}$ & $6-60$ & Triangles, pentagons and spheres & [45] \\
\hline Cassia tora leaf & Gold & $\begin{array}{l}1 \mathrm{mM} \\
\mathrm{HAuCl}_{4}\end{array}$ & $100 \mathrm{~mL}$ & $41-57$ & spherical & [46] \\
\hline $\begin{array}{l}\text { Madhuca longifolia } \\
\text { flower }\end{array}$ & Silver & $\begin{array}{l}1 \mathrm{mM} \\
\mathrm{AgNO}_{3}\end{array}$ & $30 \mathrm{~mL}$ & $30-50$ & Spherical and oval & [47] \\
\hline banana stem & Silver & $\begin{array}{l}2 \mathrm{mM} \\
\mathrm{AgNO}_{3}\end{array}$ & $9 \mathrm{~mL}$ & $\begin{array}{l}75.50 \mathrm{~nm} \text { to } \\
1.22 \mu \mathrm{m}\end{array}$ & $\begin{array}{l}\text { Truncated octahedron, rhomb-dodecahedron, } \\
\text { cubic, octahedron and octagon }\end{array}$ & [48] \\
\hline Pine cone & Silver & $\begin{array}{l}1 \mathrm{mM} \\
\mathrm{AgNO}_{3}\end{array}$ & $45 \mathrm{~mL}$ & $1-50$ & Triangular and hexagonal & [49] \\
\hline $\begin{array}{l}\text { Lycium chinense } \\
\text { fruit }\end{array}$ & Gold, Silver & $\begin{array}{l}1 \mathrm{mM} \\
\mathrm{HAuCl}_{4} \\
1 \mathrm{mM} \\
\mathrm{AgNO}_{3}\end{array}$ & $50 \mathrm{~mL}$ & $\begin{array}{l}20-100 \mathrm{~nm}, \\
50-200 \mathrm{~nm}\end{array}$ & Polydispersed, spherical & [50] \\
\hline $\begin{array}{l}\text { Ocimum sanctum } \\
\text { (tulsi) leaves }\end{array}$ & Platinum & $\begin{array}{l}1 \mathrm{mM} \\
\mathrm{H}_{2} \mathrm{PtCl}_{6}\end{array}$ & $190 \mathrm{~mL}$ & $23 \mathrm{~nm}$ & Spherical & [51] \\
\hline Diopyros kaki leaf & Platinum & $\begin{array}{l}1 \mathrm{mM} \\
\mathrm{H}_{2} \mathrm{PtCl}_{6}\end{array}$ & $190 \mathrm{~mL}$ & $2-20 \mathrm{~nm}$ & Spheres and plates & [52] \\
\hline $\begin{array}{l}\text { Curcuma longa } \\
\text { tuber }\end{array}$ & Palladium & $1 \mathrm{mM} \mathrm{PdCl}_{2}$ & $50 \mathrm{~mL}$ & 15 to $20 \mathrm{~nm}$ & Spherical & [53] \\
\hline $\begin{array}{l}\text { Musa ornate } \\
\text { flower }\end{array}$ & Iron & $\begin{array}{l}5 \mathrm{mM} \\
\mathrm{FeSO}_{4}\end{array}$ & $10 \mathrm{~mL}$ & $43.69 \mathrm{~nm}$ & & [54] \\
\hline $\begin{array}{l}\text { Calotropis } \\
\text { Gigantean flower }\end{array}$ & Iron & $\begin{array}{l}0.01 \mathrm{M} \\
\mathrm{FeNO}_{3} .9 \mathrm{H}_{2} \mathrm{O}\end{array}$ & $10 \mathrm{~mL}$ & $50-90 \mathrm{~nm}$ & Spherical & [55] \\
\hline
\end{tabular}


Table 1 Effect of biological material, precursor concentration and extract concentration on the morphology of biological nanoparticles (Continued)

\begin{tabular}{|c|c|c|c|c|c|c|}
\hline $\begin{array}{l}\text { Plant name and } \\
\text { part used }\end{array}$ & Nanoparticles & Precursor & $\begin{array}{l}\text { Concentration of } \\
\text { plant extract used }\end{array}$ & Size & Shape & References \\
\hline eucalyptus leaf & Iron & $\begin{array}{l}0.10 \mathrm{M} \\
\mathrm{FeSO}_{4}\end{array}$ & $10 \mathrm{~mL}$ & $20-80 \mathrm{~nm}$ & Spherical & [56] \\
\hline tea powder & Iron & $\begin{array}{l}0.1 \mathrm{~N} \\
\mathrm{Fe}\left(\mathrm{NO}_{3}\right)_{3}\end{array}$ & $10 \mathrm{~mL}$ & 40 to $50 \mathrm{~nm}$ & Spherical & {$[57]$} \\
\hline $\begin{array}{l}\text { Platanus orientalis } \\
\text { leaf }\end{array}$ & Iron oxide & $\mathrm{Fe}(\mathrm{NO} 3) 3$ & & $30-40 \mathrm{~nm}$ & Spherical & [58] \\
\hline Ficus carica fruit & Iron oxide & $\begin{array}{l}0.14 \mathrm{M} \\
\mathrm{FeCl}_{3} \cdot 6 \mathrm{H}_{2} \mathrm{O}\end{array}$ & $10 \mathrm{~mL}$ & $475 \mathrm{~nm}$ & Spherical & [59] \\
\hline $\begin{array}{l}\text { Conyza Canadensis } \\
\text { leaf }\end{array}$ & Zinc oxide & $\begin{array}{l}0.15 \mathrm{M} \\
\mathrm{ZnNO}_{3}\end{array}$ & $20 \mathrm{~mL}$ in $80 \mathrm{~mL}$ & - & Somewhat spherical & {$[60]$} \\
\hline Lemongrass leaves & Zinc oxide & $\mathrm{ZnNO}_{3}$ & $50 \mathrm{~mL}$ & $85-98 \mathrm{~nm}$ & Spherical & [61] \\
\hline $\begin{array}{l}\text { Hibiscus subdariffa } \\
\text { leaf }\end{array}$ & Zinc oxide & $\begin{array}{l}91 \mathrm{mM} \\
\mathrm{ZnC}_{4} \mathrm{H}_{6} \mathrm{O}_{4}\end{array}$ & $50 \mathrm{~mL}$ & $12-46 \mathrm{~nm}$ & Spherical, dumbbell shaped & {$[62]$} \\
\hline $\begin{array}{l}\text { Costus pictus } D . \\
\text { Don leaf }\end{array}$ & Zinc oxide & $\begin{array}{l}0.1 \mathrm{M} \\
\left(\mathrm{Zn}\left(\mathrm{NO}_{3}\right)_{2}\right.\end{array}$ & $50 \mathrm{~mL}$ & $40 \mathrm{~nm}$ & Elongated, hexagonal and rodshaped & {$[63]$} \\
\hline $\begin{array}{l}\text { Artemisia } \\
\text { abrotanum }\end{array}$ & $\begin{array}{l}\text { Magnesium } \\
\text { oxide }\end{array}$ & $\mathrm{Mg}\left(\mathrm{NO}_{3}\right)_{2}$ & $90 \mathrm{~mL}$ & $10 \mathrm{~nm}$ & Spherical & [64] \\
\hline $\begin{array}{l}\text { Trigonella foenum- } \\
\text { graecum leaf }\end{array}$ & $\begin{array}{l}\text { Magnesium } \\
\text { oxide }\end{array}$ & $\begin{array}{l}5 \mathrm{mM} M g \\
\left(\mathrm{NO}_{3}\right)_{2}\end{array}$ & $150 \mathrm{~mL}$ & $13 \mathrm{~nm}$ & Spherical & [65] \\
\hline $\begin{array}{l}\text { Punica granatum } \\
\text { Peels }\end{array}$ & $\begin{array}{l}\text { Magnesium } \\
\text { oxide }\end{array}$ & $\begin{array}{l}\mathrm{MgSO}_{4} 0.1 \\
\mathrm{M}\end{array}$ & $250 \mathrm{~mL}$ & $50-65 \mathrm{~nm}$ & & [66] \\
\hline $\begin{array}{l}\text { Brassica oleracea } \\
\text { flower }\end{array}$ & $\begin{array}{l}\text { Magnesium } \\
\text { oxide }\end{array}$ & $\begin{array}{l}\mathrm{MgSO}_{4} 0.1 \\
\mathrm{M}\end{array}$ & $250 \mathrm{~mL}$ & $30-45 \mathrm{~nm}$ & & \\
\hline
\end{tabular}

increased, leading to larger NPs. On the other hand, too many reducing agents may enhance the bridging effect among the formed NPs, resulting in the aggregation of NPs. This may be due to too many metal ions absorbed on the surface of preformed nuclei, where the secondary reduction process occurred leading to form larger NPs [82]. Not only size, but the shape of NPs will also get affected (Tables 1 and 2). Chandran et al. [26] and Shankar et al. [83] reported the percentage of triangles formed in the reaction medium as a function of varying amounts of the plant extract reveals that more spherical particles are formed with an increasing amount of extract. So, the optimum concentration of both the reducing agent and precursor is necessary to get the desired nanoparticle size.

\section{Effect of temperature}

As the temperature increases during nanoparticles synthesis, the rate of producing NPs from large to small size is achieved. Generally, high temperature is conducive to

Table 2 Synthesis parameters and characters of nanoparticles synthesized using plant Z. officinallae

\begin{tabular}{|c|c|c|c|c|c|c|}
\hline Nanoparticles & $\begin{array}{l}\text { Concentration } \\
\text { of precursor }\end{array}$ & $\begin{array}{l}\text { Concentration of } Z \text {. } \\
\text { officinallae extract used }\end{array}$ & Time for synthesis & Size & Shape & References \\
\hline Gold, Silver & $\begin{array}{l}1 \mathrm{mM}, \mathrm{HAuCl}_{4} \\
1 \mathrm{mM} \mathrm{AgNO}_{3}\end{array}$ & $50 \mathrm{~mL}$ & $\begin{array}{l}\text { Gold } 2.5 \mathrm{~h} \\
\text { Silver } 12 \mathrm{~h}\end{array}$ & Gold 10 nm Silver 30.31 nm & Spherical & {$[67]$} \\
\hline Silver & $1 \mathrm{mM} \mathrm{AgNO}_{3}$ & $9 \mathrm{~mL}$ & Over night & - & & {$[68]$} \\
\hline Gold & $1 \mathrm{mM}, \mathrm{HAuCl}_{4}$ & $25 \mathrm{~mL}$ & 20 min boiling & 5 to $15 \mathrm{~nm}$ & Spherical & [69] \\
\hline Silver & $1-3 \mathrm{mM} \mathrm{AgNO}_{3}$ & $25 \mathrm{~mL}$ & 30 min boiling & 6 to $20 \mathrm{~nm}$ & Spherical & {$[70]$} \\
\hline Gold, Silver & $\begin{array}{l}1 \mathrm{mM}_{1} \mathrm{HAuCl}_{4} \\
1 \mathrm{mM} \mathrm{AgNO}_{3}\end{array}$ & $45 \mathrm{~mL}$ & $10-210 \min$ & 20 to $100 \mathrm{~nm}$ & Spherical & {$[71]$} \\
\hline Gold & $0.2 \mathrm{mM} \mathrm{HAuCl}_{4}$ & $10 \mathrm{~mL}$ & $24 \mathrm{~h}$ & $3.22 \mathrm{~nm}$ & Spherical & {$[72]$} \\
\hline Silver & $1 \mathrm{mM} \mathrm{AgNO}_{3}$ & $50 \mathrm{~mL}$ & $1 \mathrm{~h}$ & $3.1 \mathrm{~nm}$ & Spherical & {$[73]$} \\
\hline Silver & $1 \mathrm{mM} \mathrm{AgNO}_{3}$ & $20 \mathrm{~mL}$ & $2 \mathrm{~h}$ & 10.10-18.33 nm & Spherical tetragonal & {$[74]$} \\
\hline
\end{tabular}


nucleation for growth for larger nanoparticles [27, 76, $84,85]$. Low temperature is conducive to growth; however, it is observed that the total reaction rate is increased with the increasing reactive temperature. Temperature exhibits different effects on the size of NPs under sufficient and insufficient quantity of the precursors due to its impressively different influence on the nucleation kinetics constant $\mathrm{k} 1$ and growth kinetics constant k2 [86]. As the reaction temperature increases, the reduction rate increases and thus most metal ions are consumed in the formation of nuclei, blocking the secondary reduction process on the surface of the preformed nuclei. Therefore, small and highly dispersed NPs are formed with increased yield [76].

The characteristics NPs synthesized using biological methods are greatly influenced by the incubation time of the reaction medium. The variations in characters during long time incubation may occur due to aggregation or shrinkage of particles; the self-life of particles may affect the potential of particles [87]. Factors governing the nanoparticles were enlisted in Table 3.

\section{Applications}

\section{Antimicrobial activity}

Development of resistance against antibiotics is threatening the scientific world globally; therefore, it is indeed to develop a pronounced novel material to alleviate against antimicrobial-resistant strains. Since antiquity, metals like copper, silver, iron, gold, magnesium, and other metals are practiced in traditional medicine. Inherently, these metals possess antimicrobial activity [88]; therefore, researchers elicited to make nano-based metallic/metal oxide NPs as an alternative for developing antimicrobial agents.

Metallic NPs generated from plant sources exhibited numerous biocidal activities against Gram-positive, Gram-negative bacterium and eukaryotes [89]. It is also reported that metallic NPs displayed effective inhibitory activity against resistant strains like Pseudomonas aeruginosa, ampicillin-resistant Escherichia coli, erythromycinresistant Streptococcus pyogenes, methicillin-resistant Staphylococcus aureus [MRSA], and vancomycinresistant Staphylococcus aureus [VRSA] [90]. In the present review, we provide the antimicrobial activity of metallic NPs synthesized from plant sources against bacterium and fungi. The antimicrobial activity of NPs depends on the type of metals used, NPs [size, shape, $\mathrm{pH}$, charge, and coating agent], genus, and species [91]. Generally, it is presumed that NPs have a high surface to volume ratio than bulk metallic counterparts, which enable them to easily interact with the cell membrane [92].

Different metallic NPs exert multiple mechanisms to counteract the microbial activity. Numerous reports have postulated the antimicrobial mechanism of NPs but until now a precise mechanism has not yet been justified for the mechanistic action of NPs. Generally, biogenic metallic/metal oxide NPs exert their bactericidal activity by releasing metal ions; interaction with cell membrane leading to damage of cell membrane and thereby formation of pits/gaps in the cell membrane leading to fragmentation of cell membrane [93]. Consequently, NPs interact with sulfur/thiol and phosphorus of proteins or DNA, leading to disruption of the metabolic process [respiratory chain, DNA replication, protein synthesis] and finally cell death [94]. Likewise, NPs exert their bactericidal activity by triggering the production of ROS followed by damaged cell wall integrity caused by phospholipid oxidation and then the internal collapse of proteins/DNA/RNA [95]. Moreover, the antibacterial activity of NPs variably differs from Gram-positive and Gram-negative bacterium due to the presence of a thick peptidoglycan layer which acts as a barrier for penetration of NPs [96].

Fungi cell architecture is made up of well cell membrane and cell wall; cell membrane is made up of phospholipids and cell wall contain mannoproteins, $\beta-1,3-$ D-glucan and $\beta-1,6-D$-glucan proteins, chitin, proteins, lipids, and polysaccharides [chitin, glucan, and mannan or galactomannan] [97]. Antifungal activity of metallic NPs is initiated by interaction with the cell wall and membrane diffusion of metal ions followed by inhibition of $\beta$-glucan synthase or on $\mathrm{N}$-acetylglucosamine [ $\mathrm{N}$-acetyl-D-glucose2-amine] an important component in the cell wall of fungi [98]. Further induction of ROS followed by oxidative stress which eventually interacts with macromolecules [DNA/RNA/Proteins] and leads to cell death [99]. In Table 4, we herein provided the antimicrobial activity of metallic nanoparticles synthesized from plants.

\section{Anti-inflammatory activity of metallic NPs}

Inflammation is a localized phenomenon that occurs as a result of injury, infection and stress by multiple

Table 3 Parameters manipulating the biosynthesis of nanoparticles

\begin{tabular}{ll}
\hline Parameters & Effect on biosynthesis of nanoparticles \\
\hline $\mathrm{pH}$ & Variability in size and shape \\
Reaction temperature & Size, shape, yield, and stability \\
Reactants concentration & Variability in shape \\
Reaction time & Increase in reaction time increases the size of metal nanoparticles \\
\hline
\end{tabular}


mechanisms like recruitment of macrophages, killer cells cytokines like IL- 1, IL- $1 \beta$, and TNF- $\alpha$ to the desired site and develops the onset of inflammation [111]. Conventionally, steroidal and nonsteroidal anti-inflammatory drugs are administered for inflammation but the side effect exerted by the drugs had an adverse effect [112]. Nano-based herbal formulation is proved as a pioneer in developing anti-inflammatory drugs. Numerous articles emphasize the metallic NPs synthesized from plant extracts endowed with anti-inflammatory properties. Recently, a study concluded that silver NPs generated from Selaginella myosurus demonstrated the antiinflammatory potential under in vivo and in vitro conditions. The study implied that AgNPs can be able to inhibit the protein denaturation, which is an important phenomenon in inflammation in the Carrageenaninduced rat hind paw edema model AgNPs that interferes with the release of acute inflammatory mediators [histamines, serotonin, kinins, prostaglandins, and cyclooxygenase products] and antagonizes their action [113]. Similarly, gold NPs synthesized from Prunus serrulata was assayed against LPS-induced RAW264.7 macrophage [114]. The results depicted that AuNPs suppressed the production of inflammatory mediators and pro-inflammatory cytokines in LPS-induced in
RAW264.7 cells by inhibiting NF-jB activation. Nagajyothi et al. [115] demonstrated that zinc oxide NPs from Polygala tenuifolia root extract displayed promising anti-inflammatory activity by inhibiting the expressions of proteins iNOS, COX-2, IL-1b, IL-6, and TNF- $\alpha$. Recently in an investigation, anti-inflammatory activities of selenium NPs coated with polysaccharide of Ulva lactua effectively inhibited the NF- $\mathrm{kB}$ protein in DSSinduced colitis mice [116]. The above-mentioned reports suggest that green synthesized metallic NPs can be able to minimize the inflammation with greater efficiency, by blocking pro-inflammatory cytokines, ROS scavenging mechanisms, and inhibiting the NF- $\mathrm{KB}$ and COX-2 pathways.

\section{Wound healing properties}

A wound is defined as sharp injuries to skin tissues where the dermal layers are cut, punctured, or torn due to response to stimuli or trauma [117]. Generally, wounds are classified into two types, namely acute and chronic wounds, based on healing time and other complications [30]. Healing of wound is a phenomenal process in which various factors intricate each other between various cell types, coagulation factors, connective tissue, growth factors, cytokines, and the vascular

Table 4 Antimicrobial activity of biological metal nanoparticles

\begin{tabular}{|c|c|c|c|c|c|}
\hline $\begin{array}{l}\text { S. } \\
\text { No }\end{array}$ & NP's & Source & Microbes & Activity & Ref \\
\hline \multirow[t]{3}{*}{1} & \multirow[t]{3}{*}{$\mathrm{TiO}_{2}$} & Hibiscus rosa-sinensis & Vibrio cholerae, Pseudomonas aeruginosa and Staphylococcus aureus & Disc diffusion method & {$[100]$} \\
\hline & & \multirow[t]{2}{*}{ M. citrifolia } & $\begin{array}{l}\text { Staphylococcus aureus, Escherichia coli, Pseudomonas aeruginosa, Bacillus } \\
\text { subtilis }\end{array}$ & \multirow[t]{2}{*}{ Agar well diffusion method } & \multirow[t]{2}{*}{ [101] } \\
\hline & & & Candida albicans Aspergillus niger & & \\
\hline 2. & Pt & Taraxacum laevigatum & Bacillus subtilis, Pseudomonas aeruginosa & MHA well diffusion method & {$[102]$} \\
\hline 3. & $\mathrm{Pd}$ & Garcinia Pedunculata & Cronobacter sakazakii & $\begin{array}{l}\text { Agar well diffusion method, } \\
\text { MIC and MBC }\end{array}$ & {$[103]$} \\
\hline \multirow[t]{2}{*}{4.} & \multirow[t]{2}{*}{ Se } & \multirow[t]{2}{*}{ Emblica officinalis } & $\begin{array}{l}\text { Escherichia coli, Listeria monocytogenes, Staphylococcus aureus, } \\
\text { Enterococcus faecalis }\end{array}$ & \multirow[t]{2}{*}{ Micro well dilution method } & \multirow[t]{2}{*}{104} \\
\hline & & & $\begin{array}{l}\text { Aspergillus brasiliensis, A. flavus, A. oryzae, A. ochraceus, Fusarium } \\
\text { anthophilum, Rhizopus stolonifer }\end{array}$ & & \\
\hline 5. & $\mathrm{Ni}$ & Monsonia burkeana & Escherichia coli, Pseudomonas aeruginosa & Broth dilution method & {$[105]$} \\
\hline \multirow[t]{2}{*}{6.} & \multirow{2}{*}{$\begin{array}{l}\text { Iron } \\
\text { oxide }\end{array}$} & \multirow[t]{2}{*}{ Acacia nilotica } & Escherichia coli, Marsa, Salmonella, Staphylococcus aureus & \multirow[t]{2}{*}{ Gel diffusion assay } & \multirow[t]{2}{*}{ [106] } \\
\hline & & & Candida & & \\
\hline 7. & $\begin{array}{l}\text { Zinc } \\
\text { oxide }\end{array}$ & Albizia lebbeck & $\begin{array}{l}\text { Bacillus cereus, Staphylococcus aureus, Escherichia coli, Klebsiella } \\
\text { pneumonia, Salmonella typhi }\end{array}$ & Disc diffusion method & {$[107]$} \\
\hline 8. & CuONPs & $\begin{array}{l}\text { Syzygium alternifolium } \\
\text { (Wt.) Walp }\end{array}$ & $\begin{array}{l}\text { Alternaria solani, Aspergillus flavus, Aspergillus niger, Penicillium } \\
\text { chrysogenum, and Trichoderma harzianum }\end{array}$ & Disc diffusion assay & [108] \\
\hline \multirow[t]{2}{*}{9} & \multirow[t]{2}{*}{$\mathrm{Au}$} & \multirow[t]{2}{*}{ Ziziphus zizyphus } & Escherichia coli & Radial diffusion assay & \multirow[t]{2}{*}{ [109] } \\
\hline & & & C. albicans & Micro dilution plate assay & \\
\hline \multirow[t]{2}{*}{10.} & \multirow[t]{2}{*}{$\mathrm{Ag}$} & \multirow[t]{2}{*}{$\begin{array}{l}\text { Erythrina suberosa } \\
\text { (Roxb.) }\end{array}$} & $\begin{array}{l}\text { Bacillus subtilis, Staphylococcus aureus, Pseudomonas aeruginosa, } \\
\text { Escherichia coli }\end{array}$ & $\begin{array}{l}\text { agar cup and micro broth } \\
\text { dilution method }\end{array}$ & \multirow[t]{2}{*}{ [110] } \\
\hline & & & C. albicans, C. kruseii, T. mentagrophytes, C. viswanathii & broth dilution method & \\
\hline
\end{tabular}


system. There are four phases of the wound healing process: (i) hemostasis phase, (ii) inflammatory phase, (iii) proliferative phase, and (iv) maturation phase. These four phases are a complex process and coordinately function altogether to heal the wound. Failure in any phase led to chronic wound and its complications are severe [118]. Moreover, other factors lead to impaired wound healing, such as diabetes, obesity, malnutrition, medication, and lifestyle habits, including excessive alcohol intake and smoking [119]. The current therapies involve the use of hyperbaric oxygen therapy, negative pressure wound therapy, bioengineered cell construct, dressing materials, and vascular surgery. Besides medications like steroidal drugs (glucocorticoid drugs), nonsteroidal drugs (ibuprofen, naproxen, rofecoxib, and celecoxib) and chemotherapeutic drugs (bevacizumab, lenvatinib, cabozantinib, brivanib, refametinib, and everolimus) are commonly practiced. But these drugs are all associated with various side effects which limit the usage [120].

In traditional medicine, plant extracts, honey, maggots, propolis, and larvae are a fascinating alternative for wound therapy [117]. But howsoever, with the advent of science and technology, researchers drive their focus in wound therapy by involving herbal extracts with nano concepts to address the specificity and complexity associated with wounds. Nano-based approaches for wound therapy is comprised of two groups; in one group, nanomaterials (metals, metal oxide, metalloid) acts as a drug for wound healing while the latter nanomaterials (growth factors, nucleic acids, small molecules) act as vehicles/delivery agent to repair wound [118].

Recently, silver NPs generated from Lindera strychnifolia claimed to have wound healing property determined by the cell scratch method on NIH3T3 cells [121]. Garg et al. [122] reported the synthesis of silver NPs from the root extract of Arnebia nobilis and formulated with hydrogel and applied in albino rats. The results demonstrated that formulated silver NPs exhibit splendid antibacterial and healing activity. Interestingly, Coleus forskohlii root extract generated silver and gold NPs displayed prominent wound healing activity in excision wounds in albino Wistar male rats [123]. Moreover, NPs do not exert a toxic effect on the animals and stimulate re-epithelialization of cells in a shorter period. Shankar et al. [124] fabricated copper oxide NPs from Ficus religosa leaf extract. The synthesized copper oxide NPs rendered superior wound healing activity and upregulated major $60,47,32,26$, and $25 \mathrm{kDa}$ proteins which play an important role in the different phases of wound repair, wound contraction, and reepithelialization process. Moniri et al. [125] reported the synthesis of magnetic NPs $\left(\mathrm{Fe}_{3} \mathrm{O}_{4}\right)$ from Aloe vera extract and impregnated the $\mathrm{Fe}_{3} \mathrm{O}_{4}$ NPs in bacterial nano cellulose (BNC) to form a nanocomposite $\mathrm{BNC} / \mathrm{Fe}_{3} \mathrm{O}_{4}$. Under in vitro conditions, $\mathrm{BNC} / \mathrm{Fe}_{3} \mathrm{O}_{4}$ nanocomposite exhibited wound healing activity in HDF cells by scratch assay. Further, $\mathrm{BNC} / \mathrm{Fe}_{3} \mathrm{O}_{4}$ nanocomposite triggers the expression of TGF- $\beta 1$, CTNNB1, MMP2, MMP9, WNT4 and downregulate the expression miR-29b and miR-29c gene. These genes play a pivotal role in the wound healing process and henceforth the nanocomposite is a prominent agent in wound healing. Shao et al. [126] reported that Barleria gibsoni leaf extractmediated zinc oxide NPs ameliorated the wound healing effectively in male albino Wistar rats. Likewise, Origanum vulgare-mediated titanium dioxide NPs improve the healing efficacy in an excised wound in male albino Wistar rats [127]. The underlying mechanism behind the wound healing efficacy is not yet clearly understood. But regarding the literature report, we can plausibly affirm that the wound healing reaction is initiated by inhibiting the proliferation of the microbial population. Further, inorganic metallic NPs induce ROS and activate angiogenesis by downregulating 38MAPK/Akt/eNOS-dependent pathway and upregulating key angiogenesis growth factors like vascular endothelial growth factor [VEGF] and fibroblast growth factor [FGF] to accelerate wound healing. Henceforth, it is very essential to understand the molecular mechanism of inorganic metallic NPsmediated wound healing process for developing metallic NPs as an alternative for wound treatment. Therefore, it is indeed to carry out extensive research to determine the effect of metallic NPs in differing phases of wound healing, toxicity, and biocompatibility to develop NPs as therapeutic potential.

\section{Anticancer activity of metallic nanoparticles}

Cancer is a dreadful global disease causing major health problems and mortality, accounting for 8.8 million deaths worldwide in 2015 [128]. Metallic NPs have been studied for their novel biological activity to induce autophagy and promote cell death. Additionally, biological metallic NPs are cytotoxic agents to fight against various types of cancer. Some recent in vitro anticancer studies of biological NPs are enlisted in Table 5 .

There are three proposed mechanisms for the anticancer activity of biological NPs. Firstly, the apoptotic pathway, which depends on an increased level of ROS which leads to oxidative stress and DNA fragmentation in the cancerous cell [141]. Secondly, interference of proteins/ DNA, resulting in cell chemistry functions. Thirdly, the interaction of biological NPs to cell membranes makes changes in the cell permeability and mitochondrial dysfunction [142, 143]. Kim et al. [144] demonstrated that the activation of p38 MAPK and Caspase- 3 at gene and protein expression levels results in response to nanoparticles. The general mechanism for anticancer activity 
Table 5 Anticancer activity of biological metal nanoparticles

\begin{tabular}{|c|c|c|c|c|}
\hline $\begin{array}{l}\text { Biological agent used } \\
\text { for synthesis }\end{array}$ & Nanoparticle & Cell line & $\mathrm{IC}_{50}$ value & Reference \\
\hline Marsilea quadrifolia & Silver & $\begin{array}{l}\text { Human ovarian teratocarcinoma (PA-1) } \\
\text { and lung adenocarcinoma (A549) }\end{array}$ & $45.88 \mu \mathrm{g} / \mathrm{mL}$ and $52.015 \mu \mathrm{g} / \mathrm{mL}$ & [25] \\
\hline Morinda pubescens & Silver & $\begin{array}{l}\text { HEP G2 (Human Epithelium cells of liver } \\
\text { cancer }\end{array}$ & $937 \mu \mathrm{g} / \mathrm{mL}$ & [129] \\
\hline Nepeta deflersiana & Silver & Human cervical cancer cells (HeLa) & $5 \mu \mathrm{g} / \mathrm{mL}$ & [130] \\
\hline Murraya koenigii & Silver & HT-29 colon cancer & $26.05 \mu \mathrm{g} / \mathrm{mL}$ & [131] \\
\hline $\begin{array}{l}\text { Cyanobacterium Nostoc sp. } \\
\text { strain HKAR-2. }\end{array}$ & Silver & MCF-7 cells & $27.5 \mu \mathrm{g} / \mathrm{mL}$ & [132] \\
\hline Piper nigrum & Silver & MCF-7 and Hep-2 cells & $52 \mathrm{~mL}, 54 \mu \mathrm{g} / \mathrm{mL}$ & [133] \\
\hline Ficus religiosa & Silver & A549 and Hep2 cells & $1.9 \mu \mathrm{g} / \mathrm{mL}$ and $1.6 \mu \mathrm{g} / \mathrm{mL}$ & [134] \\
\hline Solanum xanthocarpum & Gold & HCT 15 human colon cancer & - & [135] \\
\hline Streptomyces sp. & Gold & HeLa & $350 \mu \mathrm{g} / \mathrm{mL}$ & [136] \\
\hline Evolvulus alsinoides & Palladium & Human ovarian cancer A2780 cells & - & [137] \\
\hline Gloriosa superb & $\begin{array}{l}\text { Platinum and } \\
\text { palladium }\end{array}$ & MCF-7 (human breast adenocarcinoma & $49.65 \pm 1.99 \%$ and $36.26 \pm 0.91 \%$ & [138] \\
\hline Barleria prionitis & $\begin{array}{l}\text { Platinum } \\
\text { Paladium }\end{array}$ & Human breast adenocarcinoma (MCF-7) & - & [139] \\
\hline Sargassum muticum & $\begin{array}{l}\text { Iron oxide } \\
\text { nanoparticles }\end{array}$ & $\begin{array}{l}\text { HeLa cells, MCF-7 cells, HepG2 cells, and } \\
\text { human cell lines for leukemia Jurkat }\end{array}$ & $\begin{array}{l}1.1 \mu \mathrm{g} / \mathrm{mL}(\text { HepG2), } 18.75 \pm 2.1 \mu \mathrm{g} / \mathrm{mL} \\
\text { (MCF-7), } 12.5 \pm 1.7 \mu \mathrm{g} / \mathrm{mL} \text { (HeLa), and } \\
6.4 \pm 2.3 \mu \mathrm{g} / \mathrm{mL} \text { (Jurkat) }\end{array}$ & [140] \\
\hline Albizia lebbeck & Zinc oxide & MDA-MB 231 and MCF-7 & $48.5,48.7$, and $60.2 \mu \mathrm{g} / \mathrm{mL}$ & {$[107]$} \\
\hline $\begin{array}{l}\text { Costus pictus D. Don } \\
\text { medicinal }\end{array}$ & Zinc oxide & DLA & - & [63] \\
\hline black bean extract & Copper oxide & HeLa & - & [115] \\
\hline Ficus religiosa & Copper oxide & A549 cells & $200 \mu \mathrm{g} / \mathrm{mL}$ & [127] \\
\hline
\end{tabular}

biological NPs concluded from various studies is given in Fig. 4

The cytotoxic effect of silver NPs synthesized from Panax ginseng fresh leaves (PgAgNPs) exhibited oxidative stress in A549, MCF7, and HepG2 cancer cell lines [145]. PgAgNPs inhibits the epidermal growth factor (EGF) and enhances migration, with decreased mRNA levels and phosphorylation of EGF receptors in A549 cells. Moreover, it modified the morphology of the cell nucleus and increases apoptosis percentage; this effect was linked to the stimulation of the p38 MAPK/p53 pathway. Therefore, up/downregulation of the EGFR/ p38 MAPK/p53 pathway might be the possible mechanism of its anti cancer activity by PgAgNPs.

$\mathrm{He}$ et al [146] demonstrated in vivo and in vitro cytotoxicity of longan peel powder mediated silver NPs in H1299 cells and in the mouse model. The antagonistic effect of AgNPs was due to the inhibition of NF- $\mathrm{KB}$ activity and decrease the expression of Bcl-2/caspase- 3 and increase the survivin expression. The apoptotic effect of Ficus religiosa leaf extract-mediated copper oxide NPs induce the generation of reactive oxygen species (ROS) involving the disruption of mitochondrial membrane potential $[\Delta \psi \mathrm{m}]$ in A549 cells [147].
The gold NPs synthesized from Scutellaria barbata treated in pancreatic cancer cell lines (PANC-1) demonstrated an upregulated expression level of Caspase 3, Caspase 9, Bax and downregulated the expression of Bid and Bcl-2 [148]. The dose-dependent cytotoxicity of the PdNPs synthesized from Evolvulus alsinoides spur the production of (ROS) generation, followed by autophagy and impairment of mitochondrial membrane potential (MMP) [137].

The use of biological NPs is a blooming field in cancer therapy due to their small size and large surface area enables efficient drug delivery, tumor specificity, and promising activity. Now, it is important to conduct research using in vivo models for extending the in vitro findings and to elucidate the mechanisms of biological metallic nanoparticles for the advancement of anticancer therapy.

\section{Larvicidal activity of nanoparticles}

Vector-borne diseases are caused by bacteria, parasites, and viruses that are transmitted by vectors such as mosquitoes, ticks, sandflies, flies, and fleas. Notably, mosquitoes Aedes aegypti, Aedes albopictus, Culex quiquefasciatus, and Anopheles stephensi are the vectors 


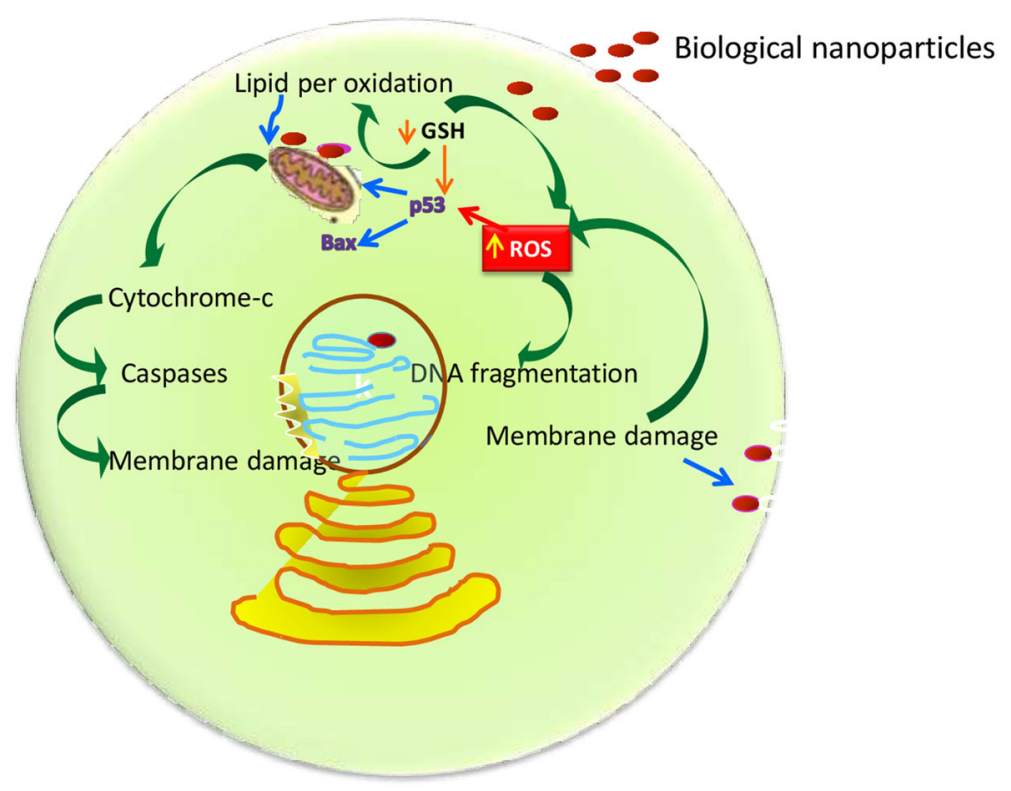

Fig. 4 Cytotoxic mechanism of biological nanoparticles

that transmit diseases like dengue fever, chikungunya, malaria, yellow fever, lymphatic filariasis, Japanese encephalitis, and West Nile fever [149]. The prevalence of vector-borne diseases in India is very high due to favorable climatic conditions transmitting the diseases exponentially. Governmental agencies framework a layout Pest management Program to control and mitigate the mosquito population through a comprehensive approach [150]. Various strategies have been developed to control mosquito larvae and adult but the eradication of mosquitoes completely is a bottleneck factor for researchers. Larvicides and adulticides are utilized routinely to disrupt the growth of mosquitoes but adulticides are less effective technique in mosquito control [151]. Larvicides are an excellent agent that promotes the disruption of larvae at their breeding sites drastically. Conventionally, larvicides like synthetic insecticide dichlorodiphenyltrichloroethane [(DDT), organochlorines, pyrethroids, and pyrethrins] carbamates and organophosphates, organochlorine cyclodiene and phenylpyrazoles gave positive results and effective to all kinds of mosquitoes at different stages [152]. But howsoever, due to massive usage, mosquitoes start to build up resistance against insecticide. Moreover, insecticides also pose unwanted toxicity to non-target organisms, human beings, and the environment. Considering the pitfalls associated with insecticide, early researchers drive their focus to develop botanical insecticides from plant sources. As a result, plants Azadirachta indica, Nicotiana tabacum, Ocimum basilicum, Cinnamomum osmophloeum and plant bases oils have proved the potential as larvicides [153]. At the present scenario, numerous plants and their derivatives have been excelled as a botanical insecticide and some of them are commercialized. As the progress of science and technology, researchers drive their research by formulating nano formulated herbal drugs. It is very indeed at this juncture by combining plants and its products in the nano module to counteract the larvicidal populations.

Table 6 sums up the plant-mediated metallic nanoparticles and their larvicidal activity. The NPs exhibited antagonistic activity against the different instar larvae of mosquitoes. Plant-mediated metallic nanoparticles displayed prominent activity in a dose-dependent manner. Moreover, the effect of larvicidal activity of NPs is directly proportional to the genus and species of mosquitoes, larvae stages, and plant moieties that coat the NPs, size, shape, and charge [154]. All these factors govern the larvicidal efficacy of NPs. The widely accepted precise mechanism behind the NPs toxicity is that they induce oxidative stress in tissues of arthropods. Another study concludes that NPs exert their toxicity by penetrating the cavity of the exoskeleton followed by interaction with sulfur from proteins or phosphorous from DNA leading to rapid denaturation of enzymes and organelles [155, 156]. Jiang et al. [157] also reported that decrease in membrane permeability and disturbance in proton motive force may also lead to impairment of cellular function and death. Subsequently, to shed light on the consequences of exposed NPs, Kalimuthu et al. [158] reported that Hedychium coronarium J. Koenig rhizome-synthesized Ag NPs damaged the midgut epithelial cells of $A$. aegypti revealed by histopathological study. Sundararajan and Kumari 
Table 6 Larvicidal activity of metallic nanoparticles synthesized from plant sources

\begin{tabular}{|c|c|c|c|c|c|}
\hline S. No & NPs & Plant & Species & $\mathrm{LC}_{50}$ & Ref \\
\hline 1. & $\mathrm{Ag}$ & Curcuma zedoaria & Culex quinquefasciatus & $0.57 \mathrm{ppm}$ & [160] \\
\hline 2. & & $\begin{array}{l}\text { Holarrhena } \\
\text { antidysenterica (L.) Wall. }\end{array}$ & Aedes aegypti; Culex quinquefasciatus & 5.53 ppm; 9.3 ppm & [161] \\
\hline 3. & $\mathrm{Au}$ & Artemisia vulgaris $L$. & Aedes aegypti & 62.47 ppm & [159] \\
\hline 4. & & Chloroxylon swietenia DC & $\begin{array}{l}\text { Aedes aegypti } \\
\text { Anopheles stephensi }\end{array}$ & $\begin{array}{l}0.423 \mathrm{ppm} \\
0.602 \mathrm{ppm}\end{array}$ & [162] \\
\hline 5. & $\mathrm{Cu}$ & Tridax procumbens & Aedes aegypti & 4.209 ppm & [163] \\
\hline 6. & $\mathrm{CuO}$ & Artocarpus heterophyllus & Aedes aegypti & 5.08 ppm & [164] \\
\hline 7. & $\mathrm{ZnO}$ & Scadoxus multiflorus & Aedes aegypti & 34.04 ppm & [165] \\
\hline 8. & $\mathrm{ZnO}$ & Momordica charantia & $\begin{array}{l}\text { Anopheles stephensi } \\
\text { Culex quinquefasciatus }\end{array}$ & $\begin{array}{l}5.42 \mathrm{ppm} \\
4.87 \mathrm{ppm}\end{array}$ & [166] \\
\hline 9. & $\mathrm{Fe}$ & Ficus natalensis & $\begin{array}{l}\text { Aedes aegypti } \\
\text { Anopheles stephensi } \\
\text { Culex quinquefasciatus }\end{array}$ & 35.9 ppm & [167] \\
\hline 10. & $\mathrm{Ni}$ & Aegle marmelos & $\begin{array}{l}\text { Aedes aegypti } \\
\text { Anopheles stephensi } \\
\text { Culex quinquefasciatus }\end{array}$ & $\begin{array}{l}534.83 \mathrm{ppm} \\
595.23 \mathrm{ppm} \\
520.83 \mathrm{ppm}\end{array}$ & [168] \\
\hline 11. & $\mathrm{Pd}$ & Cocos nucifera & Aedes aegypti & 259.24 ppm & [169] \\
\hline 12. & $\mathrm{Se}$ & Clausena dentata & $\begin{array}{l}\text { Aedes aegypti } \\
\text { Anopheles stephensi } \\
\text { Culex quinquefasciatus }\end{array}$ & $\begin{array}{l}104.13 \mathrm{ppm} \\
240.71 \mathrm{ppm} \\
99.60 \mathrm{ppm}\end{array}$ & [170] \\
\hline 13. & Tio2 & Morinda citrifolia & $\begin{array}{l}\text { Aedes aegypti } \\
\text { Anopheles stephensi } \\
\text { Culex quinquefasciatus }\end{array}$ & $\begin{array}{l}18.62 \mathrm{ppm} \\
5.71 \mathrm{ppm} \\
33.69 \mathrm{ppm}\end{array}$ & [171] \\
\hline 14. & & Mangifera indica & $\begin{array}{l}\text { Anopheles subpictus } \\
\text { Culex quinquefasciatus }\end{array}$ & $\begin{array}{l}7.72 \mathrm{ppm} \\
8.10 \mathrm{ppm}\end{array}$ & [172] \\
\hline
\end{tabular}

[159] observed that Artemisia vulgaris L. mediate gold NPs damage the midgut, epithelial cell, and cortex of A. aegypti with the accumulation of $\mathrm{Au}$ inside the midgut region. In the above-reported studies, accumulation of metals in the thorax and abdomen is a common phenomenon that occurred; this accumulation leads to various complications like ROS generation and cell death.

\section{Antiviral activity of metallic nanoparticles}

Another important research to be addressed by the researchers is the antiviral properties of green nanomaterials. Viruses are one of the contagious agents causing various diseases in humans, plants, and animals. In particular, the severity of viral diseases in human is panic and cause detrimental effects in human beings [173]. Notably, viruses like influenza, hepatitis, herpes simplex virus [HSV], and human immunodeficiency virus [HIV] are life-threatening to humans. These viruses cause pathologically complicated diseases and if left untreated or vaccinated it will worsen or in some cases, death may occur [174]. In the present scenario, numerous antibiotics identified from plant and microbial sources have been developed and formulated and commercialized as antiviral agents [175]. These drugs exert their mechanism effectively, but prolonged administration of drugs causes the virus to build up resistance mechanisms [176]. In the crusade to develop fabricated nano drugs for antiviral therapy, plant-based metallic nanoparticles have open up the potential to combat viral diseases.

Among the metallic nanoparticles, silver NPs are ranked top in antiviral NPs. This is due to the fact that application of silver as an eye solution for the treatment of conjunctivitis [177]. Later, silver NPs synthesized using chemical methods were evaluated against HIV, herpes, Influenza, and hepatitis virus [178]. These results were clinically significant and pave the way for developing NPs as antiviral agents. Despite the facts, concerning the toxicity of metallic nanoparticles through the chemical methods, an alternative strategy should be adopted. Recently, Haggag et al. [179] postulated the green synthesized silver NPs of Lampranthus coccineus and Malephora lutea and performed splendid antiviral activity against $\mathrm{HSV}-1, \mathrm{HAV}-10$, and CoxB4 viruses. The antiviral activity of silver NPs can plausibly confirm that silver NPs bind with viral envelope glycoprotein and inhibit the process. Silver NPs integrate with the viral genome and also inhibit viral replication [178]. Though 
there are numerous reports on the antiviral activity of metallic nanoparticles synthesized by chemical methods, but until now, there are no scientific reports related to the antiviral activity of plant-mediated metallic nanoparticles except silver. Hence, it is indeed to explore the possibilities of plant metallic nanoparticles to study the antiviral activity.

\section{Leishmanicidal activity of nanoparticles}

Leishmaniasis is another important life-threatening disease caused by the parasite Leishmania transmitted by the sandfly Phlebotomus species [180]. Pathologically, Leishmaniasis can be classified based on severity and intensity as visceral, cutaneous, and postkalaazar dermal leishmaniasis, mucocutaneous leishmaniasis [181]. The therapeutic efficacy of Leishmaniasis has relied on the utilization of antileishmania drugs, but some drugs suffer from resistance mechanisms like increased efflux mechanism, decreased drug concentration inside the parasite, inhibition of drug activation, and inactivation of active drug which hampers the drug activity [182].

Naturally, plants bear the active ingredients to perform antagonistic activity against bacterial and viral infections. Ullah et al. [183] synthesized silver NPs through the chemical and biological method from the aqueous extract of Teucrium stocksianum and evaluated for antileishmanicidal activity. The study outputs that both chemical and biogenic NPs demonstrated strong antagonistic assay against Leishmania infantum promastigotes with $\mathrm{IC}_{50}$ value $30.71 \pm 1.91 \mu \mathrm{g} / \mathrm{mL}$ for biogenic AgNPs and $51.23 \pm 2.20 \mu \mathrm{g} / \mathrm{mL}$ of chemically synthesized silver NPs. Moreover, the infectivity of Leishmania parasites (treated with chemical and biogenic AgNPs) on macrophages cells was observed by Giemsa staining in the infected macrophages. By MTT assay, the study resulted that chemical AgNPs exert high toxicity while compared with biogenic AgNPs. Ahmad et al. [184] reported the synthesis of gold NPs from an extract of Maytenus royleanus and evaluated against Leishmania tropica promastigotes. The in-vitro assay resulted that AuNPs drastically reduced the viability of L. tropica in a shorter period. Likewise, $\mathrm{ZnO}$ NPs were synthesized from Mirabilis jalapa leaf extract were shown to eradicate the viability of the Leishmania parasite and cause a lethal toxic effect at a concentration of 0.5 M [185]. Similarly, Rosmarinus officinalis-mediated iron oxide NPs effectively inhibited the viability of $L$. major in a dose-dependent manner with an $\mathrm{LC}_{50}$ value of $350 \mu \mathrm{g} / \mathrm{mL}$ [186]. The plausible mechanism antileishmanicidal activity of NPs is hypothesized to be NPs binds with the cell membrane and cause intracellular damage (mitochondria) and inhibition of enzyme synthesis which consequently leads to high-level production of ROS and trigger apoptosis.

\section{Antioxidant activity}

Free radicals are highly reactive unstable atoms or molecules with outermost unpaired electrons generated by reactive oxygen species (ROS). These are responsible for the number of human diseases like atherosclerosis and cancer including brain damage and chronic complications in the physiological system. The electronic configuration of metallic nanoparticles is ready to accept or donate an electron to quench free radicals [187]. Recent reports prescribe that biological NPs synthesized from plants such as copper [ $\left.\mathrm{IC}_{50} 500 \mu \mathrm{g} / \mathrm{mL}\right]$, copper oxide, gold $\left[\mathrm{IC}_{50} 50 \mu \mathrm{g} / \mathrm{mL}\right.$ ], silver [IC $\mathrm{I}_{50} 73.27 \mu \mathrm{g} / \mathrm{mL}$ ], magnesium oxide [ $\mathrm{IC}_{50} 4.73 \mu \mathrm{g} / \mathrm{mL}$ ], and zinc oxide [ $\mathrm{IC}_{50}$ $127.74 \mu \mathrm{g} / \mathrm{mL}$ ] [30, 68, 72, 188-190] shown a radical scavenging activity with significant $\mathrm{IC}_{50}$ value. Antioxidant activity of Albizia lebbeck stem bark extractmediated $\mathrm{ZnO}$ NPs was carried out using $\mathrm{H}_{2} \mathrm{O}_{2}$ free radical scavenging assay which revealed higher $\mathrm{IC}_{50}$ values of $48.5,48.7$, and $60.2 \mu \mathrm{g} / \mathrm{mL}$ for $0.1 \mathrm{M}, 0.05 \mathrm{M}$, and $0.01 \mathrm{M} \mathrm{ZnO} \mathrm{NPs,} \mathrm{respectively} \mathrm{[111].} \mathrm{The} \mathrm{result} \mathrm{ob-}$ tained from the antioxidant activity study of Artemisia abrotanum herb and MgO NPs synthesized using the $A$. abrotanum indicated the high antioxidant activity shown by $\mathrm{MgO}$ NPs $[4.73 \mu \mathrm{g} / \mathrm{mL}]$ as compared to the herb $[6.28 \mu \mathrm{g} / \mathrm{mL}]$ itself. Most of the studies are based on 1,1diphenyl-2-picrylhydrazyl (DPPH) assay while some studies also include nitric oxide, hydrogen peroxide, superoxide, and reducing power assays. The method of synthesis, reducing biological material used for synthesis, and capping agent acquired by nanoparticle play an important role in the antioxidant activity of that nanoparticle [191].

\section{Toxicity}

As the field of nanotechnology began to grow, the potential toxicity of these novel materials is unveiling after its use. Scientists and toxicologists were involved in the safety and evaluation of NPs but very few reports are available on the green NPs toxicity [192]. Butea monosperma-mediated silver NPs had shown a therapeutic index of 3.77 when tested over $24 \mathrm{~h}$ on human myeloid leukemia (KG-1A) cells and in human peripheral blood mononuclear cells (PBMC) [193]. Biological metallic NPs synthesized from Abutilon inducum, Butea monosperma, Gossypium hirsutum, Indoneesiella echioides, and Melia azedarach are among the potential anticancer agents with an acceptable therapeutic index as their therapeutic index values were $\geq 2.0$ when tested on both cancer cells and normal human cells [194]. 
Silver NPs synthesized rapidly using sulfated polysaccharide extract from Sargassum siliquosum, a brown alga when given up to $2000 \mathrm{mg} / \mathrm{kg}$ did not cause mortality to rats but caused minimal elevation of serum creatinine and blood urea nitrogen [195]. However, silver NPs synthesized using Ficus religiosa leaf extract when administrated in rats revealed a significant increase in serum levels of AST, ALT, and LDH, TNF-a and IL-6 on day 29. These levels reverted to normal at the end of the washout period on day 89. ICP-OES analysis revealed the accumulation of silver in the liver, brain, and lungs on day 29 with the respective concentrations of 4.77 , 3.94 , and $3.043 \mu \mathrm{g} / \mathrm{g}$ tissue. However, complete elimination of silver was observed on day 89 . Histological analysis performed in vital organs indicated pathological changes only in the liver which was also normalized after 89 days [136].

Rheder et al. [196] demonstrated the importance of performing toxicological and ecotoxicological evaluations of new NPs, since although they may provide the desired bactericidal and anticancer effect, their toxicity could threaten the survival of organisms. Althaea officinalis-mediated silver NPs cause oxidative stress followed by the increase in CAT and decrease in GPx and GST even in the lower concentration and in almost all tissues. In this circumstance, it seems to reflect an aggravation status due to reduced cell protection ability to protect fish against ROS under stress conditions caused by these NPs. Olive, mulberry, and figmediated silver and sulfur have a significant effect on larvae, pupae, and adult mortality and they have decreased larval longevity significantly [197]. Sengottaiyan et al. [198] demonstrated that the Solanum nigrum phyto-synthesized silver NPs significantly improved the bodyweight loss in diabetic rats. It also retrieved the total cholesterol and triglyceride levels compared to the normal group for 21 days of administration. While Vasanth and Kurian [199] studied nephrotoxicity of silver NPs prepared by chemical and green route [aqueous extract of Desmodium gangeticum root] in rat, proximal epithelial cell lines and renal mitochondria were evaluated by oral administration of silver NPs $[100 \mathrm{mg} / \mathrm{kg}]$ to the Wistar rats. After 15 days, significant changes in the renal architecture were observed in both receiving rats, supported by the urine and blood chemistry data. Further, exposure toward renal epithelial cells and renal mitochondria also confirm the toxic similarities between the silver NPs synthesized from two routes.

Green-synthesized gold NPs from Curcuma mangga $(\mathrm{CM})$ were found to have good stability in physiological media after $24 \mathrm{~h}$ of dispersion. It is also cytocompatible with human colon fibroblast cells (CCD-18Co) and human lung fibroblast cells (MRC-5). Hemocompatibility tests revealed that these gold NPs were blood-compatible, with less than $10 \%$ of hemolysis without any aggregation of erythrocytes. This study suggests the potential in employing a CM- extract-based method in the preparation of gold nanoparticles for anticancer diagnosis and therapy [200].

A systemic study on the accumulation of Helianthus tuberosus-mediated gold NPs in rats revealed that gold element concentration accumulated in the liver, lung, kidney, and spleen. The study showed a that the lung is the major target organ and further suggests that enduring administration could lead to organ damage as majorly observed in lung tissue. This study suggests the necessity of complete in vivo toxicity analysis, before introducing NPs in biomedical applications [201].

At present, there are very few reports of biocompatibility study of biological metal nanoparticles on animal models that have been available [202, 203]. The atomic economy of biological NPs is controlled by the reduction efficiency of plant molecules that affect the number of surface atoms, single or agglomerated form, uncapped or partially capped or fully capped, morphology, and possibility of unreduced metallic ions these all factors, in turn, affects the cytotoxicity of biological NPs during toxicity study of biological NPs. The quick, efficient, economic protocol needs to develop toxicity study NPs [198].

\section{Other applications of metallic nanoparticles}

With the growing awareness in nano-based themes and applications, the nano-based sensor is occupying an eminent role in scientific studies. Metal nanoparticles are preferentially used in the transducer component of sensors; that too silver, gold, and platinum is widely used. Though reports on nanosensors are practiced in glucose detection, immunosensors, aptamers. But here, the green metallic nanoparticles as a nano-sensor are utilized in very few studies only. Alex et al. [204] reported the sensitivity of biologically synthesized silver nanoparticles and compared their sensitivity with others and concluded that biological silver nanoparticles showed high sensitivity which can be employed in various cost-effective and eco-friendly sensor devices applications. They have demonstrated the sensitivity of silver nanoparticles toward MCZ fungicide with the $39.1 \mathrm{~nm} / \mathrm{mM}$. In another study, the sensitivity of gold nanoparticles synthesized using C. nudiflora plant extract was used for the detection of HCG hormone in pregnant women urine with $100 \%$ accuracy [205]. Similarly, gold nanoparticles can be employed as a biosensor to determine the glucose content in commercial glucose injections was successfully achieved and performed [206].

\section{Future research and outlook of metallic nanoparticles}

With the inception of NPs over a half-century, the perception of NPs is still now not clearly understood by the researchers. Green chemistry philosophy warrants the 
synthesis of NPs as an eco-friendly alternative for conventional methods of NPs synthesis. Moreover, the green chemistry approach of NPs synthesis stands on the viewpoint that NPs synthesis should be a benign process, utilization of natural resources, avoiding usage of hazardous materials, free from toxicity and cost inexpensive.

Hitherto, numerous reports have documented the synthesis of metal/metal oxide NPs using the resources plants, bacteria, fungi, yeast, and actinomycetes. Among the natural resources, plants are widely employed for NPs synthesis owing to the ethnobotanical value, active ingredients, easily available, simplified process, and cost inexpensive. Despite the facts, there are a lot of key issues and technical challenges to be addressed by the researchers to develop green NPs as a successful one.

Physical and chemical-based methods of NPs synthesis produce uniformity, homogeneity, and mono NPs but in biological-based, it is questionable.

The following are the key issues about green NPs synthesis and development:

$>$ Lack of holistic knowledge to develop green NPs using plants entity.

$>$ The logical strategy should be adopted to develop

green NPs with discrete size and shape.

$\gg$ Uniformity of NPs should be ensured. Plant-

mediated NPs produce more variant size, shape, and structure.

$>$ Conversion of salt to ion is the main challenge to be addressed. In plant-mediated synthesis, the maximum conversion of salt to ion should be accomplished.

$>$ The precise role of plant molecules in NPs should be elucidated. These molecules act as a reducing and stabilizing agent.

$>$ Whether the NPs fabricated are homogenous since there is a difference in substance [biological resources] utilized for synthesis.

$\triangleright$ The transfer of technology processes should be implemented to fabricate NPs from the lab to the industrial level.

$>$ Industrial production of NPs should have come with a benign method focusing on ease of synthesis, utilization of resources, particle generation [monodispersity, uniformity, reproducibility], waste management, and toxicity perspective.

$>$ It is a distant dream to produce NPs completely free from toxicity. In our review also, we explain the potential threat of toxicity of plant-mediated metallic nanoparticles to humans and the environment. Henceforth, at least researchers should be directed to fabricate NPs with minimal toxicity.

$>$ It is also imperative to understand the ecotoxicological perspective of metallic NPs for environmental applications. Studies on the aquatic ecosystem, various habitats on niche areas, nontarget organisms should also be carried out.

Another important and most serious concern to be addressed is the utilization of NPs in biomedical applications. Infectious diseases are caused by bacteria, viruses, fungi, and parasites. In practice, routine usage of antibiotics led to the development of resistance mechanisms by microbes. In some cases, these antibiotics also create toxicity to humans and they are nonselective too.

We are living in an exciting age where these size dependencies offer both challenges and opportunities, and that, if we take the appropriate approach, this will give us more room for discoveries and applications.

\section{Conclusion}

Herein, we have comprehensively provided the recent trends in the synthesis of metallic nanoparticles through plants only. The present review aims to the concept and demands the need for a synthesis of metallic nanoparticles from various plants. Moreover, we strongly focused on the challenges encountered in the synthesis of nanoparticles and characterization convincingly. Further, we advocated the applications of metallic nanoparticles such as antimicrobial, antioxidant, anticancer, anti-inflammatory, wound healing, larvicidal, and leishmanicidal activities of metallic nanoparticles in context with recent findings. Finally, we highlighted the future perspective of metallic nanoparticles with strong recommendations and necessitate the changes to be adopted for developing metallic nanoparticles as a safe biocompatible agent. Overall, considering all the above scientific merits and demerits of metallic nanoparticles, researchers tune their research toward metallic nanoparticles from plants by ease process and develop such kinds of metallic nanoparticles as theranostics for various infectious and noninfectious diseases.

\footnotetext{
Abbreviations

NP: Nanoparticles; CN: Carbon nanotubes; MN: Metal nanoparticles; CN: Ceramic nanoparticles; SN: Semiconductor nanoparticles; SLIPS: Slippery liquid-infused porous surface; CVD: Chemical vapor deposition; RPM: Rotation per minute; $\mathrm{pH}$ : Potential of hydrogen ion concentration; UV-Vis spectra: Ultraviolet-visible spectroscopy; Au: Gold; HRTEM: High-resolution transmission electron microscopy; MRSA: Methicillin-resistant Staphylococcus aureus; VRSA: Vancomycin-resistant Staphylococcus aureus; IL: Interleukins; TNF: Tumor necrosis factor; AgNPs: Silver nanoparticles; LPS: Lipopolysaccharide/endotoxin; AuNPs: Gold nanoparticles; ROS: Reactive oxygen species; NF: Necrosis factor; COX: Cytochrome oxidase; kDa: Kilo Dalton; $\mathrm{Fe}_{3} \mathrm{O}_{4}$ : Iron oxide; BNC: Bacterial nano cellulose; VEGF: Vascular endothelial growth factor; FGF: Fibroblast growth factor; EGF: Epidermal growth factor; LDH: Lactate dehydrogenase;

DDT: Dichlorodiphenyltrichloroethane.; HSV: Herpes simplex virus; HIV: Human immunodeficiency virus; IC: Inhibitory concentration; $\mu \mathrm{g} /$ $\mathrm{mL}$ : Microgram/milliliter; ZnO NPs: Zinc oxide nano particles; LC: Lethal
} 
concentration; DPPH: 1,1-Diphenyl-2-picrylhydrazyl; MTT: 3[4,5 Dimethylthiozole-2yl]-2,5 diphenyltetrazolium bromide; XTT: 3-bis-[2Methoxy-4-nitro-5-sulfophenyl]-2H-tetrazolium-5-carboxanilide; ICPOES: Inductively coupled plasma-optical emission spectrometry: CAT: Catalase; GST: Glutathione S-transferase; GPx: Glutathione peroxidase

\section{Acknowledgements}

We would like to gratitude the administrative authorities of Karpagam Academy of Higher Education for their support and encouragement to execute the review project.Authors greatly acknowledge the Department of Science and Technology, India for their support vide reference no. SR/WOSA/LS-1196/2015, under the Woman Scientist Scheme-A to carry out this review.

\section{Availability of data and material}

Not applicable.

\section{Authors' contributions}

$\mathrm{SP}$-acquisition, analysis, and interpretation of metallic nanoparticles synthesis and other applications. RC — drafted the manuscript. All authors read and approved the final manuscript.

\section{Funding}

There is no role of funding source in this review project.

\section{Ethics approval and consent to participate}

Not applicable.

\section{Consent for publication}

Not applicable.

\section{Competing interests}

The authors declare that they have no competing interests.

\section{Author details}

'Department of Microbiology, Karpagam Academy of Higher Education, Coimbatore, India. ${ }^{2}$ Department of Biotechnology, Sri Krishna College of Arts and Science, Coimbatore, India. ${ }^{3}$ Department of Biotechnology, Karpagam Academy of Higher Education, Coimbatore, India.

\section{Received: 3 July 2020 Accepted: 28 September 2020}

\section{Published online: 26 October 2020}

\section{References}

1. Thiruvengadam M, Rajakumar G, Chung IM (2018) Nanotechnology: current uses and future applications in the food industry. 3 Biotech. 8(2018):1-13. https://doi.org/https://doi.org/10.1007/s13205-018-1104-7

2. Jeevanandam J, Barhoum A, Chan YS, Dufresne A, Danquah MK (2018) Review on nanoparticles and nanostructured materials: history, sources, toxicity and regulations.Beilstein J. Nanotechnol. 9(2018):1050-1074. https:// doi.org/10.3762/bjnano.9.98

3. Chandrasekaran R, Yadav SA, Sivaperumal S (2019) Phytosynthesis and characterization of copper oxide nanoparticles using the aqueous extract of Beta vulgaris $L$ and evaluation of their antibacterial and anticancer activities. J Clust Sci 6(2019). https://doi.org/10.1007/s10876-019-01640-6

4. Chandrasekaran R, Rajiv P, Kamel A, Abd-Elsalam (2020) Carbon nanotubes: plant gene delivery and genome editing Carbon Nanomaterials for Agrifood and Environmental Applications. 279-296. https://doi.org/10.1016/ B978-0-12-819786-8.00014-1 (c) 2020 Elsevier Inc.

5. Khan I, Saeed K, Khan I (2019)Nanoparticles: Properties, applications and toxicities, Arab J Chem 12: 908-931. https://doi.org/10.1016/j.arabjc. (2017).05.011

6. Bhatia S(2016) Nanoparticles types, classification, characterization, fabrication methods and drug delivery applications. Natural Polymer Drug Delivery systems, In: Natural Polymer Drug Delivery Systems. Springer, Cham, Springer International Publishing Switzerland. https://doi.org/10.1007/978-3319-41129-3 2

7. Gentile A, Ruffino F, Grimaldi MG (2016) Complex-morphology metal-based nanostructures: fabrication, characterization, and applications. Nanomaterials. 6(2016). https://doi.org/10.3390/nano606qa110
8. Griffin S, Masood MI, Nasim MJ, Sarfraz M, Ebokaiwe AP, Schäfer K, Keck CM, Jacob C (2018) Natural nanoparticles: a particular matter inspired by nature. (n.d.). 7(2018). https://doi.org/10.3390/antiox7010003

9. Azharuddin M, Zhu GH, Das D, Ozgur E, Uzun L, Turner APF (2019) Patra HK (2019) a repertoire of biomedical applications of noble metal nanoparticles. Chem Commun 55:6964-6996. https://doi.org/10.1039/c9cc01741k

10. Srinoi $P$, Chen $Y T$, Vittur $V$, Marquez MD, Lee TR (2018) Bimetallic nanoparticles: enhanced magnetic and optical properties for emerging biological applications. Appl Sci (Switzerland) 7(2018). https://doi.org/10. 3390/app8071106

11. Seetharaman PK, Chandrasekaran R, Gnanasekar S, Chandrakasan G, Gupta M, Manikandan DB, Sivaperumal S (2018) Antimicrobial and larvicidal activity of eco-friendly silver nanoparticles synthesized from endophytic fungi Phomopsis liquidambaris. Biocatal Agric Biotechnol 16:22-30. https://doi. org/10.1016/j.bcab.(2018).07.006

12. Gwo S, Chen HY, Lin MH, Sun L, Li X (2016) Nanomanipulation and controlled self-assembly of metal nanoparticles and nanocrystals for plasmonics. Chem Soc Rev 45:5672-5716. https://doi.org/10.1039/ c6cs00450d

13. Meyers MA, Mishra A, Benson DJ (2006) Mechanical properties of nanocrystalline materials. Prog.Mater.Sci. 51:427-556. https://doi.org/10. 1016/j.pmatsci.2005.08.003

14. Thakkar KN, Mhatre SS, Parikh RY (2010) Biological synthesis of metallic nanoparticles. Nanomedicine 6:257-262. https://doi.org/10.1016/j.nano. 2009.07.002

15. Decarolis D, Odarchenko Y, Herbert JJ, Qiu C, Longo A, Beale AM (2019) Identification of the key steps in the self-assembly of homogeneous gold metal nanoparticles produced using inverse micelles. Phys Chem Chem Phys. https://doi.org/https://doi.org/10.1039/c9cp03473k. No volume and page number on paper

16. Dhand C, Dwivedi N, Loh XJ, Jie Ying AN, Verma NK, Beuerman RW, Lakshminarayanan R, Ramakrishna S (2015) Methods and strategies for the synthesis of diverse nanoparticles and their applications: a comprehensive overview. RSC Adv 5 (2015):105003-105037. https://doi.org/https://doi.org/ 10.1039/c5ra19388e

17. Prasad Yadav T, Manohar Yadav R, Pratap Singh D (2012) Mechanical milling: a top down approach for the synthesis of nanomaterials and nanocomposites, Nanosci Nanotechnol 2 (2012):22-48. https://doi.org/ https://doi.org/10.5923/j.nn.(2012)0203.01.

18. Seetharaman PK, Chandrasekaran R, Gnanasekar S, Chandrakasan G, Gupta M, Manikandan DB (2018) Sivaperumal S (2018) antimicrobial and larvicida activity of eco-friendly silver nanoparticles synthesized from endophytic fungi Phomopsis liquidambaris. Biocatal Agric Biotechnol 16:22-30

19. DarroudiM, Sabouri Z, Kazemi R, Oskuee, Khorsand Zak A, Kargar H, Hamid MHNA, (2013) Sol-gel synthesis, characterization, and neurotoxicity effect of zinc oxide nanoparticles using gum tragacanth. Ceram Int, 39 (2013): 91959199. https://doi.org/https://doi.org/10.1016/j.ceramint.2013.05.021

20. Zhang M, Yang J, Cai Z, Feng Y, Wang Y, Zhang D, Pan X (2019) Detection of engineered nanoparticles in aquatic environments: current status and challenges in enrichment, separation, and analysis, Environ Sci Nano 6 (2019): 709-735. https://doi.org/https://doi.org/10.1039/c8en01086b.

21. Kalishwaralal K, Barathmanikanth S, Ram S, Pandian K, Deepak V, Gurunathan S (2010) Colloids and surfaces B : biointerfaces silver nanoparticles impede the biofilm formation by Pseudomonas aeruginosa and Staphylococcus epidermidis, Colloids Surf B: Biointerfaces 79 (2010): 340-344. https://doi. org/https://doi.org/10.1016/j.colsurfb.2010.04.014.

22. Karunakaran G, Jagathambal M, Gusev A, Antonio J, Torres L, Kolesnikov E, Kuznetsov D (2016) Rapid biosynthesis of AgNPs using soil bacterium Azotobacter vinelandii with promising antioxidant and antibacterial activities for biomedical applications. J O M. 69 https://doi.org/https://doi. org/10.1007/s11837-016-2175-8.

23. Phanjom P, Ahmed G (2017) Effect of different physicochemical conditions on the synthesis of silver nanoparticles using fungal cell filtrate of Aspergillus oryzae (MTCC No. 1846 ) and their antibacterial effect. Adv. Nat. Sci. Nanosci. Nanotechnol. 8 (2017). https://doi.org/https://doi.org/10.1088/ 2043-6254/aa92bc.

24. Ahmad A, Senapati S, Khan MI, Kumar R, Sastry M (2003) Extracellular biosynthesis of monodisperse gold nanoparticles by a novel extremophilic Actinomycete. Langmuir 2003:3550-3553

25. Subbiah M, Sivamurugan V (2017) Green synthesis, characterization of silver nanoparticles of a marine red alga spyridia fusiformis and their antibacterial 
alga spyridia fusiformis. Int J Pharm Pharm, 9 (2017): 192-197. https://doi. org/https://doi.org/10.22159/ijpps.2017v9i5.17105.

26. Rao B, Tang R (2017)Green synthesis of silver nanoparticles with antibacterial activities using aqueous Eriobotrya japonica leaf extract. Adv. Nat. Sci.: Nanosci. Nanotechnol. 8 (2007):1-8. https://doi.org/10.1088/20436254/aa5983.

27. Moosa AA, Ridha AM (2015) Al-kaser M (2015) process parameters for green synthesis of silver nanoparticles using leaves extract of aloe vera plant process parameters for green synthesis of silver nanoparticles using leaves extract of aloe vera plant. Int J Multidiscipl Curr Res 3:966-975

28. Li X, Xu H, Chen ZS, Chen G (2011) Biosynthesis of nanoparticles by microorganisms and their applications. J Nanomater 2011:270974

29. Southam G, Beveridge TJ (1994) The in vitro formation of placer gold by bacteria. Geochim Cosmochim Acta 58(20):4527-4530

30. Eming SA, Martin P, Tomic-Canic M (2014) Wound repair and regeneration mechanisms. Sci Transl Med. 322 (2014): 265sr6. https://doi.org/https://doi. org/10.1126/scitransImed.3009337.Wound.

31. Kalishwaralal K, Deepak V, Ramkumarpandian S, Nellaiah H, Sangiliyandi G (2008) Extracellular biosynthesis of silver nanoparticles by the culture supernatant of bacillus licheniformis. Mat Lett 62(29):4411-4413

32. Durán N, Marcato PD, Alves OL, De Souza GIH, Esposito E (2005) Mechanistic aspects of biosynthesis of silver nanoparticles by several Fusarium oxysporum strains. J Nanobiotechnol 3:8. https://doi.org/10.1186/1477-3155-3-

33. Singh J, Dutta T, Kim KH, Rawat M, Samddar P, Kumar P (2018) 'Green'synthesis of metals and their oxide nanoparticles: applications for environmental remediation. J Nanobiotech 16(1):84

34. Roy A, Bulut O (2019) SomeS, Mandal AK, Yilmaz MD (2019) Green synthesis of silver nanoparticles: biomolecule-nanoparticle organizations targeting antimicrobial activity. RSC Adv 9:2673-2702. https://doi.org/10.1039/ c8ra08982e

35. Chandran SP, Chaudhary M, Pasricha R, Ahmad A, Sastry M (2006) Synthesis of gold nanotriangles and silver nanoparticles using Aloe vera plant extract. Biotechnol Prog 22:577-583

36. Armendariz V, Herrera I, Peralta-videa JR, Jose-Yacaman M (2004) Size controlled gold nanoparticle formation by Avena sativa biomass : use of plants in nanobiotechnology. J Nanopart Res 6:377-382

37. Ara N, Mondal S, Basu S, Laskar RA, Mandal D (2009) Biogenic synthesis of au and Ag nanoparticles using aqueous solutions of black tea leaf extracts. Colloids and surfaces $B$.

38. Sathishkumar M, Forbes E, Sneha K, Yun Y (2009) Cinnamon zeylanicum bark extract and powder mediated green synthesis of nano-crystalline silver particles and its bactericidal activity. Int J Mater Sci 73 (2009):332-338. https://doi.org/https://doi.org/10.1016/j.colsurfb.2009.06.005.

39. Philip D (2010) Green synthesis of gold and silver nanoparticles using Hibiscus rosa sinensis. Phys E Low-Dimensional Syst Nanostructures 42 (2010):1417-1424. https://doi.org/https://doi.org/10.1016/j.physe.2009.11.081.

40. Philip D, Unni C (2011) Extracellular biosynthesis of gold and silver nanoparticles using Krishna tulsi (Ocimum sanctum) leaf. Phys. E LowDimensional Syst. Nanostructures. 43 (2011):1318-1322. https://doi.org/ https://doi.org/10.1016/.jphyse.2010.10.006.

41. Parashar V, Parashar R, Sharma B, Pandey AC (2009) Parthenium leaf extract mediated synthesis of silver nanoparticles : a novel approach towards weed utilization. Digest Journal of Nanomaterials and Biostructures, 4 (2009): 45-50.

42. Ghodake GS, Deshpande NG, Lee YP, Jin ES (2010) Pear fruit extract-assisted room-temperature biosynthesis of gold nanoplates, colloids and surfaces B: Biointerfaces75 (2010):584-589. https://doi.org/https://doi.org/10.1016/j. colsurfb.2009.09.040.

43. Ankamwar, B, Chaudhary, M, Sastry, M, Ankamwar, B, n.d. (2005) Nanotriangles biologically synthesized using tamarind. Synth React Inorg Met Org Nano Met Chem 35(2005):19-26. https://doi.org/https://doi.org/10.1081/SIM-200047527.

44. Park JS, Park Y (2017) Asymmetric dumbbell-shaped silver nanoparticles and spherical gold nanoparticles green- synthesized by mangosteen (Garcinia mangostana) pericarp waste extracts. Int J Nanomedicine 12(2017):6895-6908

45. Kumar KM, Mandal BK, Sinha M, Krishnakumar, V (2012) Terminalia chebula mediated green and rapid synthesis of gold nanoparticles. Spectrochim Acta Part A Mol Biomol Spectrosc 86 (2012):490-494. https://doi.org/https:// doi.org/10.1016/j.saa.2011.11.001.

46. Elumalai E, Preetam A, John R (2016) Characterization and in vitro studies on anticancer, antioxidant activity against colon cancer cell line of gold nanoparticles capped with Cassia tora SM leaf extract. Appl Nanosci. (2016): 121-129. https://doi.org/https://doi.org/10.1007/s13204-015-0422-x.

47. Patil MP, Singh RD, Koli PB, Patil KT, Jagdale BS, Tipare AR, Kim, G (2018) Antibacterial potential of silver nanoparticles synthesized using Madhuca longifolia flower extract as a green resource. Microb Pathog 124 (2018):124189. https://doi.org/https://doi.org/10.1016/.micpath.2018.05.040.

48. Das J, Velusamy P (2013) Biogenic synthesis of antifungal silver nanoparticles using aqueous stem extract of banana. Nano Biomed Eng (2013):34-39. https://doi.org/https://doi.org/10.5101/nbe.v5i1.p34-38.1.

49. Velmurugan P, Lee $S$ (2013) Pine cone-mediated green synthesis of silver nanoparticles and their antibacterial activity against agricultural pathogens. Bioprocess Biosyst Eng (2013):361-368. https://doi.org/https://doi.org/10. 1007/s00253-012-3892-8.

50. Chokkalingam M, Singh P, Huo Y, Soshnikova V, Ahn S, Kang J, Mathiyalagan R, Kim YJ, Yang DC (2018) Facile synthesis of au and Ag nanoparticles using fruit extract of Lycium chinense and their anticancer activity. J Drug Deliv Sci Technol 49:308-315. https://doi.org/10.1016/j.jddst.2018.11.025

51. Soundarrajan C, Sankari A, Dhandapani P, Maruthamuthu S, Ravichandran S, Sozhan G, Palaniswamy N (2012) rapid biological synthesis of platinum nanoparticles using Ocimum sanctum for water electrolysis applications. Bioprocess Biosyst Eng 35 (2012): 827-833. https://doi.org/https://doi.org/10. 1007/s00449-011-0666-0.

52. Yong J, Kwon SEE (2010) Kwon, Biological synthesis of platinum nanoparticles using Diopyros kaki leaf extract. Bioprocess. Biosyst. Eng. 33 (2010): 159-164. https://doi.org/https://doi.org/10.1007/s00449-009-0373-2.

53. Sathishkumar M, Forbes E, Sneha K, Yun Y (2009) Palladium nanocrystal synthesis using Curcuma longa tuber extract. Int J Mater Sci 4:11-17

54. Saranya S (2017) Green synthesis of iron nanoparticles using aqueous extract of Musa ornata flower sheath against pathogenic bacteria. Indian J Pharm Sci 79(2017):688-694

55. Sravanthi K, Ayodhya D, Swamy PY (2018) Green synthesis, characterization of biomaterial-supported zero-valent iron nanoparticles for contaminated water treatment. J Anal Sci Technol 9 (2018). https://doi.org/https://doi.org/ 10.1186/s40543-017-0134-9.

56. Wang T, Jin X, Chen Z, Megharaj M, Naidu R (2014) Science of the total environment green synthesis of Fe nanoparticles using eucalyptus leaf extracts for treatment of eutrophic wastewater. Sci Total Environ (2014): 210-213. https://doi.org/https://doi.org/10.1016/.scitotenv.2013.07.022.

57. Nadagouda MN, Castle AB, Murdock RC, Hussain M, Varma RS (2010) In vitro biocompatibility of nanoscale zerovalent iron particles (NZVI) synthesized using tea polyphenols. Green Chem 12 (2010):114-122. https://doi.org/ https://doi.org/10.1039/b921203p.

58. Devi HS, Boda MA, Shah MA, Parveen S (2018) Parveen, green synthesis of iron oxide nanoparticles using Platanus orientalis leaf extract for antifungal activity. Green Process Synth 8 (2019):38-45. https://doi.org/https://doi.org/ 10.1515/gps.2017.0145

59. Demirezen DA, Yalç S, Demirezen D (2018) Green synthesis and characterization of iron oxide nanoparticles using Ficus carica (common fig) dried fruit extract. J Biosci Bioeng 127 :5-9. https://doi.org/https://doi.org/ 10.1016/j.jbiosc.2018.07.024.

60. Ali J, Irshad R, Li B, Tahir K (2018) Synthesis and characterization of phytochemical fabricated zinc oxide nanoparticles with enhanced antibacterial and catalytic applications J Photochem Photobiol B Biol 183 (2018):349-356. https://doi.org/https://doi.org/10.1016/j.jphotobiol. 2018.05.006.

61. Kumari P, Kumar H, Kumar J, Sohail M, Singh K, Prasad K (2019) Biosynthesized zinc oxide nanoparticles control the growth of Aspergillus flavus and its aflatoxin production. International Journal of Nano Dimension 10(4):320-329

62. Bala N, Saha S, Chakraborty M, Maiti M (2015) Green synthesis of zinc oxide nanoparticles using hibiscus subdariffa leaf extract: effect of temperature on synthesis, anti-bacterial activity and anti- diabetic activity. RCS Adv 7 (2015) https://doi.org/https://doi.org/10.1039/C4RA12784F.

63. Suresh J, Pradheesh G, Alexramani V (2018) Green synthesis and characterization of zinc oxide nanoparticle using insulin plant (Costus pictus D. Don) and investigation of its antimicrobial as well as anticancer activities. Advances in Natural Sciences: Nanoscience and Nanotechnology. 9 (2018). https://doi.org/https://doi.org/10.1088/2043-6254/aaa6f1

64. Dobrucka R (2018)Synthesis of MgO nanoparticles using Artemisia abrotanum Herba extract and their antioxidant and Photocatalytic 
properties. Iran J Sci Technol Trans A Sci 42 (2018):547-555. https://doi.org/ 10.1007/s40995-016-0076-X.

65. Vergheese M, Vishal SK (2018) Green synthesis of magnesium oxide nanoparticles using Trigonella foenum-graecum leaf extract and its antibacterial activity. J Pharmacogn Phytochem 7:1193-1200

66. Sugirtha P, Divya R, Yedhukrishnan R, Suganthi KS, Anusha N, Ponnusami V, Rajan KS (2015) Green synthesis of magnesium oxide nanoparticles using Brassica oleracea and Punica granatum peels and their anticancer and photocatalytic activity. Asian J Chem. 27:2513-2517. https://doi.org/https:// doi.org/10.14233/ajchem.2015.17965

67. Singh C, Sharma V, Naik PK, Khandelwal V, Singh H (2011) A green biogenic approach for synthesis of gold and silver nanoparticles using Zingiber officinale

68. Saraswathi K, Vidhya J, Mohanapriya L, Arumugam P (2016) Green synthesis of silver nanoparticles using Zingiber officinale extract and evaluation of their antioxidant, antimicrobial and anti-inflammatory effect. WJPPS. 5 (2016):12191233. https://doi.org/https://doi.org/10.20959/wjpps.2016.11-8028.

69. K.P. Kumar KP, Paul W, Sharma CP (2013) Green synthesis of gold nanoparticles with Zingiber officinale extract : characterization and blood compatibility. Process Biochem 46 (2013). https://doi.org/https://doi.org/10. 1016/j.procbio.2011.07.011.

70. Kumar KP, Paul W, Sharma CP (2013) Green synthesis of silver nanoparticles with Zingiber officinale extract and study of its blood compatibility green synthesis of silver nanoparticles with Zingiber officinale extract and study of its blood compatibility. J Nanopart Res 2 (2012):144-152. https://doi.org/ https://doi.org/10.1007/s12668-012-0044-7.

71. Velmurugan P, Anbalagan K, Manosathyadevan M (2014) Green synthesis of silver and gold nanoparticles using Zingiber officinale root extract and antibacterial activity of silver nanoparticles against food pathogens. Bioprocess Biosyst Eng 37 (2014):1935-1943. https://doi.org/https://doi.org/ 10.1007/s00449-014-1169-6.

72. Gargi D, Dipankar H, Atanu M (2018) Synthesis of gold colloid using Zingiber officinale : catalytic study. Nano Mat Chem Bio Dev 1:10-14

73. Shalaby TI, Mahmoud OA, Batouti GAE, Ibrahim EE (2015) Green synthesis of silver nanoparticles : synthesis, characterization and antibacterial activity. Nanosci Nanotechnol 5 (2015):23-29. https://doi.org/https://doi.org/10.5923/ j.nn.2015.0502.01.

74. El AA, Gehan R, Ayman AG, Khateeb Y, El, Hassaan MM (2018) Eco-friendly synthesis of metal nanoparticles using ginger and garlic extracts as biocompatible novel antioxidant and antimicrobial agents. J Nanostructure Chem 8 :71-81. https://doi.org/https://doi.org/10.1007/s40097-018-0255-8.

75. Mohammad Mousavi-Khattat, Mehrnaz Keyhanfar \& Amir Razmjou (2018) A comparative study of stability, antioxidant, DNA cleavage and antibacterial activities of green and chemically synthesized silver nanoparticles, Artificial Cells, Nanomedicine, and Biotechnology, 46

76. Yang N, Li W (2013) Mango peel extract mediated novel route for synthesis of silver nanoparticles and antibacterial application of silver nanoparticles loaded onto non-woven fabrics. Ind Crop Prod 48 (2013):81-88. https://doi. org/https://doi.org/10.1016/j.indcrop.2013.04.001.

77. Ndikau M, Noah NM, Andala, DM, Masika E (2017) Green synthesis and characterization of silver nanoparticles using Citrullus lanatus fruit rind extract. Int J Analytical Chem 2017 (2017). https://doi.org/https://doi.org/10. 1155/(2017)/8108504

78. Velgosová O, Mražíková A, Marcinčáková R (2016) Influence of pH on green synthesis of Ag nanoparticles. Mater Lett 180 (2016):336-339. https:/doi.org/ https://doi.org/10.1016/j.matlet.2016.04.045.

79. Chitra K, Annadurai G (2014) Antibacterial activity of pH-dependent biosynthesized silver nanoparticles against clinical pathogen. Bio Med Research International (2014). https://doi.org/https://doi.org/10.1155/ (2014)/725165.

80. Barisik M, Atalay S, Beskok A, Qian S (2014) Size dependent surface charge properties of silica nanoparticles. J Phys Chem C 118:1836-1842

81. Anigol LB, Charantimath JS, Gurubasavaraj PM (2017) Effect of concentration and $\mathrm{pH}$ on the size of silver nanoparticles synthesized by green chemistry. Organic \& Medicinal Chem. 3 (2017):1-5. https://doi.org/10.19080/OMCIJ. (2017).03.555622.

82. Rokade SS, Joshi KA, Mahajan K, Tomar G, Dubal DS, Singh V, Kitture R, Bellare J, Ghosh S (2017) Novel anticancer platinum and palladium nanoparticles from Barleria prionitis. Micro. \& Nano. Letters 2 (2017):1-9. https://doi.org/10.19080/GJN.(2017).02.555600.
83. Shankar SS, Rai A, Ahmad A, Sastry M (2005) Controlling the optical properties of lemongrass extract synthesized gold nanotriangles and potential application in infrared-absorbing optical coatings. Chem Mater 17:566-572

84. Kaviya S, Santhanalakshmi J, Viswanathan B (2011) Green synthesis of silver nanoparticles using Polyalthia longifolia leaf extract along with D-sorbitol: study of antibacterial activity. JNanotechnol (2011). https://doi.org/10.1155/ (2011)/152970.

85. Kredy HM (2018) The effect of $\mathrm{pH}$, temperature on the green synthesis and biochemical activities of silver nanoparticles from Lawsonia inermis extract. J Pharm Sci Res 10(2018):7-12

86. Liu H, Zhang H, Wang J, Wei J (2017) Effect of temperature on the size of biosynthesized silver nanoparticle : deep insight into microscopic kinetics analysis. Arab J Chem 13 (2017):1011-1019. https://doi.org/https://doi.org/ 10.1016/j.arabjc.(2017).09.004.

87. Patra JK, Baek K (2014) Green nanobiotechnology : factors affecting synthesis and characterization techniques, Journal of Nanomaterials Synthesis (2014). https://doi.org/https://doi.org/10.1155/(2014)/417305

88. Galib Barve M, Mashru M, Jagtap C, Patgiri BJ, Prajapati PK (2011) Therapeutic potentials of metals in ancient India: a review through Charaka Samhita. J Ayurveda Integr Med 2 (2011):55-63. https://doi.org/https://doi. org/10.4103/0975-9476.82523.

89. Eltarahony M, Zaki S, Elkady M, Abd-El-Haleem D (2018) Biosynthesis, characterization of some combined nanoparticles, and its biocide potency against a broad spectrum of pathogens. J Nanomater (2018). https://doi. org/https://doi.org/10.1155/(2018)/5263814.

90. Baptista PV, McCusker MP, Carvalho A, Ferreira DA, Mohan NM, Martins M, Fernandes AR(2018) Nano-strategies to fight multidrug resistant bacteria-"A Battle of the Titans". Front. Microbiol. 9 (2018):1-26. https://doi:10.3389/ fmicb.(2018).01441

91. Wang L, Hu C, Shao L (2017) The-antimicrobial-activity-of-nanoparticles-present-situati, Int J Nanomedicine 12 (2017) 1227-1249. https://doi.org/ https://doi.org/10.2147/JN.S121956.

92. Slavin YN, Asnis J, Häfeli UO, Bach H (2017) Metal nanoparticles: understanding the mechanisms behind antibacterial activity. J. Nanobiotechnology. 15 (2017):1-20. https://doi.org/https://doi.org/10.1186/ s12951-017-0308-z.

93. Rajkuberan C, Sudha K, Sathishkumar G, Sivaramakrishnan S (2015) Antibacterial and cytotoxic potential of silver nanoparticles synthesized using latex of Calotropis gigantea L. Spectrochim Acta - Part A Mol Biomol Spectrosc. 136 (2015): 924-930. https://doi:https://doi.org/10.1016/j.saa. (2014).09.115

94. Rajkuberan C, Prabukumar S, Sathishkumar G, Wilson A, Ravindran K, Sivaramakrishnan S (2017) Facile synthesis of silver nanoparticles using Euphorbia antiquorum L. latex extract and evaluation of their biomedical perspectives as anticancer agents. J. Saudi Chem. Soc. 21(2017): 911-919. https://doi:10.1016/j.jscs.(2016).01.002

95. Karakoti AS, Hench LL, Seal S (2006) The potential toxicity of nanomaterials - the role of surfaces. JOM. 58: 77-82. https://doi.org/https:// doi.org/10.1007/s1 1837-006-0147-0

96. Chandrasekaran R, Seetharaman P, Krishnan M, Gnanasekar S, Sivaperumal S (2018) Carica papaya (papaya) latex: a new paradigm to combat against dengue and filariasis vectors Aedes aegypti and Culex quinquefasciatus (Diptera: Culicidae). 3 Biotech. 8 (2018): 1-10. https://doi.org/https://doi.org/ 10.1007/s13205-018-1105-6.

97. Xia T, Kovochich M, Liong M, Mädler L, Gilbert B, Shi H, Yeh Jl, Zink Jl, Nel AE (2008) Comparison of the mechanism of toxicity of zinc oxide and cerium oxide nanoparticles based on dissolution and oxidative stress properties. ACS Nano 2 (2008): 2121-2134. https://doi.org/https://doi.org/10. 1021/nn800511k.

98. Romero M, Cantón E, Pemán J, Gobernado M (2005) Antifúngicos inhibidores de la síntesis del glucano. Rev Esp Quimioter 18:281-299

99. Arciniegas-Grijalba PA, Patiño-Portela MC, Mosquera-Sánchez LP, Guerrero-Vargas, JA, Rodríguez-Páez JE (2017) ZnO nanoparticles (ZnONPs) and their antifungal activity against coffee fungus Erythricium salmonicolor. Appl Nanosci 7 (2017): 225-241. https://doi.org/https://doi. org/10.1007/s13204-017-0561-3.

100. Sahaya P, Kumar M, Francis AP, Devasena T (2014) Biosynthesized and chemically synthesized titania nanoparticles : comparative analysis of antibacterial activity. J. Environ. Nanotechnol. 3 (2014): 73-81. https://doi. org/https://doi.org/10.13074/jent.(2014).09.143098. 
101. Sundrarajan M, Bama K, Bhavani M, Jegatheeswaran S, Ambika S, Sangili A, Nithya P, Sumathi R (2017) Obtaining titanium dioxide nanoparticles with spherical shape and antimicrobial properties using M. citrifolia leaves extract by hydrothermal method. J Photochem Photobiol B Biol. 171 (2017): 117124. https://doi.org/https://doi.org/10.1016/j.jphotobiol.(2017)05.003.

102. Tahir K, Nazir S, Ahmad A, Li B, Ullah A, UI Z, Khan H, Ullah F, Ullah Q, Khan A, Ur A (2017) Facile and green synthesis of phytochemicals capped platinum nanoparticles and in vitro their superior antibacterial activity. JPB. 166 (2017): 246-251. https://doi.org/https://doi.org/10.1016/j.jphotobiol. (2016).12.016.

103. Hazarika M, Borah D, Bora P, Silva AR, Das P (2017) Biogenic synthesis of palladium nanoparticles and their applications as catalyst and antimicrobial agent. PLoS One 2017:1-19

104. Gunti L, Dass RS, Kalagatur NK (2019) Phytofabrication of selenium nanoparticles from Emblica officinalis fruit extract and exploring its biopotential applications : antioxidant, antimicrobial, and biocompatibility. Front Microbiol, 10 (2019): 1-17. https://doi.org/https://doi.org/10.3389/ fmicb.(2019).00931.

105. Kganyago P, Mahlaule-Glory LM, Mathipa MM, Ntsendwana B, Mketo N, Mbita Z, Hintsho-Mbita NC (2018) Synthesis of NiO nanoparticles via a green route using Monsonia burkeana: the physical and biological properties. J Photoch Photobio B 182:18-26

106. Da E, Taha A, Afkar E (2018) Green synthesis of iron nanoparticles by Acacia nilotica pods extract and its catalytic, adsorption , and antibacterial activities. Appl Sci 8 (2018). https://doi.org/https://doi.org/10.3390/ app8101922.

107. Umar H, Kavaz D, Rizaner N (2019) Biosynthesis of zinc oxide nanoparticles using albizia lebbeck stem bark, and evaluation of its antimicrobial, antioxidant, and cytotoxic activities on human breast cancer cell lines. Int J Nanomedicine 14 (2019): 87-100. https://doi.org/ https://doi.org/10.2147/IJN.S186888.

108. Yugandhar P, Vasavi T, Uma P, Devi M (2017) Bioinspired green synthesis of copper oxide nanoparticles from Syzygium alternifolium ( Wt .) Walp : characterization and evaluation of its synergistic antimicrobial and anticancer activity. Appl Nanosci. 7 (2017): 417-427. https://doi.org/https:// doi.org/10.1007/s13204-017-0584-9.

109. AljabaliAAA, Akkam Y, Salim M, Zoubi A, Al-batayneh KM, Id BA, Alrob O.A, AlkilanyAM, Benamara M, Id DJE, (2018) Synthesis of gold nanoparticles using leaf extract of Ziziphus zizyphus and their antimicrobial activity. Nanomat.8 (2018): 1-15. https://doi.org/https://doi.org/10.3390/ nano8030174.

110. Mohanta Y.K, Panda S.K, Jayabalan, R, Sharma N (2017) Antioxidant and cytotoxic activity of silver nanoparticles synthesized by leaf extract of Erythrina suberosa (Roxb). Front Mol Biosci 4 (2017): 1-9. https://doi.org/ https://doi.org/10.3389/fmolb.(2017).00014

111. Agarwal, H, Nakara A, Shanmugam, V.K (2019) Anti-inflammatory mechanism of various metal and metal oxide nanoparticles synthesized using plant extracts: a review. Biomed Pharmacother 109 (2019): 2561-2572. https://doi.org/https://doi.org/10.1016/j.biopha.(2018).11.116.

112. Ong CKS, Lirk P, Tan CH, Seymour RA (2007) An evidence-based update on nonsteroidal anti-inflammatory drugs. Clin Med Res 5 (2007): 19-34. https:// doi.org/https://doi.org/10.3121/cmr.(2007).698.

113. Kedi PBE, Meva FE, Kotsedi L, Nguemfo EL, Zangueu CB, Ntoumba AA, Mohamed HEA, DongmoAB, Maaza M (2018) Eco-friendly synthesis, characterization, in vitro and in vivo anti-inflammatory activity of silver nanoparticle-mediated Selaginella myosurus aqueous extract. Int J Nanomedicine 13 (2018): 8537-8548. https://doi.org/https://doi.org/10. 2147/IJN.S174530

114. Singh P, Ahn S, Kang JP, Veronika S, Huo Y, Singh H, Chokkaligam M, ElAgamy Farh M, Aceituno VC, Kim YJ, Yang DC (2018) In vitro antiinflammatory activity of spherical silver nanoparticles and monodisperse hexagonal gold nanoparticles by fruit extract of Prunus serrulata: a green synthetic approach. Artif Cells, Nanomedicine Biotechnol. 46 (2018): 20222032. https://doi.org/https://doi.org/10.1080/21691401.(2017).1408117.

115. Nagajyothi PC, Cha SJ, Yang IJ, Sreekanth TVM, Kim KJ, Shin HM (2015) antioxidant and anti-inflammatory activities of zinc oxide nanoparticles synthesized using Polygala tenuifolia root extract. J Photochem Photobiol B Biol 146 (2015): 10-17. https://doi.org/https://doi.org/10. 1016/j.jphotobiol.(2015).02.008

116. Zhu C, Zhang S, Song C, Zhang Y, Ling Q, Hoffmann PR, Li J, Chen T, Zheng W, Huang Z (2017) Selenium nanoparticles decorated with Ulva lactuca polysaccharide potentially attenuate colitis by inhibiting NF-KB mediated hyper inflammation. J Nanobiotechnology 15 (2017): 1-15. https://doi.org/ https://doi.org/10.1186/s12951-017-0252-y.

117. Nethi SK, Das S, Patra CR, Mukherjee S (2019) Recent advances in inorganic nanomaterials for wound-healing applications. Biomater Sci 7 (2019): 26522674. https://doi.org/https://doi.org/10.1039/c9bm00423h.

118. Hamdan S, Pastar I, Drakulich S, Dikici E, Tomic-Canic M, Deo S, Daunert S (2017) Nanotechnology-driven therapeutic interventions in wound healing: potential uses and applications. ACS Cent Sci 3 (2017): 163-175. https://doi. org/https://doi.org/10.1021/acscentsci.6b00371.

119. Anderson K, Hamm RL (2012) Factors that impair wound healing. J Am Coll Clin Wound Spec 4 (2012): 84-91. https://doi.org/https://doi.org/10.1016/j. jccw.(2014).03.001.

120. Ovais M, Zia N, Ahmad I, KhalilAT, Raza A, Ayaz M, Sadiq A, Ullah F, Shinwari ZK (2018). Phyto-therapeutic and nanomedicinal approaches to cure Alzheimer's disease: present status and future opportunities. Front Aging Neurosci. 10 (2018): 1-23. https://doi.org/https://doi.org/10.3389/fnagi.(2018).00284

121. Ahn EY, Jin H, Park Y (2019) Assessing the antioxidant, cytotoxic, apoptotic and wound healing properties of silver nanoparticles green-synthesized by plant extracts. Mater. Sci. Eng. C. 101 (2019): 204-216. https://doi.org/https:// doi.org/10.1016/j.msec.(2019).03.095.

122. Garg S, Chandra A, Mazumder, A, Mazumder R (2014) Arnebia nobilis root extract and wound healing potential of its hydrogel. Mater Sci Eng (2014): 95-101. https://doi.org/https://doi.org/10.4103/0973-8398.134925.

123. Naraginti S, Kumari PL, Das RK, Sivakumar A, Patil SH, Andhalkar W (2016) Amelioration of excision wounds by topical application of green synthesized, formulated silver and gold nanoparticles in albino Wistar rats. Mater Sci Eng C 62 (2016): 293-300. https://doi.org/https://doi.org/10.1016/j. msec.(2016).01.069.

124. Sankar R, Dhivya R, Shivashangari KS, Ravikumar V (2014) Wound healing activity of Origanum vulgare engineered titanium dioxide nanoparticles in Wistar albino rats. J Mater Sci Mater Med 25 (2014): 1701-1708. https://doi. org/https://doi.org/10.1007/s10856-014-5193-5.

125. Moniri M, MoghaddamAB, Azizi S, Rahim RA, Saad WZ, Navaderi M, Arulselvan P, Mohamad R (2018) Molecular study of wound healing after using biosynthesized BNC/Fe 304 nanocomposites assisted with a bioinformatics approach. Int J Nanomedicine 13 (2018): 2955-2971. https:// doi.org/https://doi.org/10.2147/IJN.S159637.

126. Shao F, Yang AJ, Yu DM, Wang J, Gong X, Tian HX (2018) Bio-synthesis of Barleria gibsoni leaf extract mediated zinc oxide nanoparticles and their formulation gel for wound therapy in nursing care of infants and children. J Photochem Photobiol B Biol 189(2018):267-273. https://doi.org/10.1016/j. jphotobiol.(2018).10.014

127. Sankar R, Baskaran A, Subramanian K (2015) Inhibition of pathogenic bacterial growth on excision wound by green synthesized copper oxide nanoparticles leads to accelerated wound healing activity in Wistar albino rats. J Mater Sci Mater Med. 26. https://doi.org/https://doi.org/10.1007/ s10856-015-5543-y.

128. Metrics GH (2017) Global, regional, and national incidence, prevalence, and years lived with disability for 328 diseases and injuries for 195 countries, 1990 - (2016) : a systematic analysis for the Global Burden of Disease Study. The Lancet. 390 (2017): 1990-(2016). https://doi.org/10.1016/S01406736(17)32154-2.

129. Inbathamizh L, Ponnu TM (2012) Mary EJ (2012) in vitro evaluation of antioxidant and anticancer potential of Morinda pubescens synthesized silver nanoparticles free radicals. JOPR J Pharm Res 6:32-38. https://doi.org/ 10.1016/j.jopr.(2012).11.010

130. Al-Sheddi ES, Farshori NN, Al-Oqail MM, Al-Massarani SM, Saquib Q, Wahab R, Musarrat J, Al-Khedhairy AA, Siddiqui MA (2018) Anticancer potential of green synthesized silver nanoparticles using extract of Nepeta deflersiana against human cervical cancer cells (HeLA). Bioinorg Chem Appl:1-12. https://doi.org/10.1155/(2018)/9390784

131. Cancer HC, Line C, Roshni K, Younis M, llakkiyapavai D, Basavaraju P, Puthamohan VM (2018) Cancer science \& therapy anticancer activity of biosynthesized silver nanoparticles using Murraya koenigii leaf extract against HT-29 colon cancer cell line. J Cancer Sci Ther 10:72-75. https://doi. org/10.4172/1948-5956.1000521

132. Sonker AS, Pathak J, Vinod K, Sinha RP (2017) Characterization and in vitro antitumor, antibacterial and antifungal activities of green synthesized silver nanoparticles using cell extract of Nostoc sp. strain. Can J Biotech. 1: 26-37. https://doi.org/https://doi.org/10.24870/cjb.(2017)-000103. 
133. Krishnan V, Bupesh G, Manikandan EKTA, Magesh S, Kalyanaraman R, Maaza M (2016) Green synthesis of silver nanoparticles using Piper nigrum concoction and its anticancer activity against MCF-7 and Hep-2 cell lines. J Antimicrobial Agents 2(2016):8-12. https://doi.org/10.4172/ 2472-1212.1000123

134. Ju S, Jun I, Tettey CO, Mo K, Mook H (2016) In-vitro anticancer activity of green synthesized silver nanoparticles on MCF-7 human breast cancer cells. Mater Sci Eng C. 68 (2016): 430-435. https://doi.org/https://doi.org/10.1016/j. msec.(2016).03.101.

135. Zhang P (2018) Synthesis of gold nanoparticles with Solanum xanthocarpum extract and their in vitro anticancer potential on nasopharyngeal carcinoma cells. Int J Nanomedicine 13(2018):7047-7059

136. Manivasagan P, Oh J (2015) Production of a novel fucoidanase for the green synthesis of gold nanoparticles by Streptomyces sp. and its cytotoxic effect on HeLa cells. Mar Drugs. 13 (2015): 6818-6837. https://doi.org/ https://doi.org/10.3390/md13116818.

137. Gurunathan S, Kim E, Han JW, Park JH, Kim J (2015) Green chemistry approach for synthesis of effective anticancer palladium nanoparticles. Molecules. 20 (2015): 22476-22498. https://doi:https://doi.org/10.3390/ molecules 201219860

138. Rokade SS, Joshi KA, Mahajan K, Patil S, Tomar G, Dubal DS, Parihar VS, Kitture R, Bellare JR (2018) Gloriosa superba mediated synthesis of platinum and palladium nanoparticles for induction of apoptosis in breast cancer citation Gloriosa superba mediated synthesis of platinum and palladium nanoparticles for induction of apoptosis in breast cancer. Bioinorg Chem Appl. https://doi.org/10.1155/(2018)/4924186

139. Rokade SS, Joshi KA, Mahajan K, Tomar G, Dubal DS, Singh V, Kitture R, Bellare J, Ghosh S (2017) Novel anticancer platinum and palladium nanoparticles from Barleria prionitis. Glob J Nano 2(5):555600

140. Namvar F, Rahman HS, Mohamad R, Baharara J, Mahdavi M, Amini E, Chartrand MS, Yeap S K (2014) Cytotoxic effect of magnetic iron oxide nanoparticles synthesized via seaweed aqueous extract. Int J Nanomedicine (2014): 2479-2488.

141. Singh G, Babele PK, Shahi SK, Sinha RP, Tyagi MB, Kumar AA (2014) Green synthesis of silver nanoparticles using cell extracts of. Anabaena doliolum and screening of its antibacterial and antitumor activity 24(2014):1354-1367. https://doi.org/10.4014/jmb.1405.05003

142. Lim ZJ, Li JJ, Ng C, Yung LL, Bay B (2011) Gold nanoparticles in cancer therapy. Nat Publ Gr 32: 983-990. https://doi.org/https://doi.org/10.1038/ aps.(2011).82.

143. Patil S, Sivaraj R, Vanathi R (2015) Anticancer potential of green synthesized silver nanoparticles : a review.International. J Curr Res 7(2015):21539-21544

144. Kim CG, Castro-Aceituno V, Abbai R, Lee HA, Simu SY, Han Y, Yang DC (2018) Caspase-3/MAPK pathways as main regulators of the apoptotic effect of the phyto-mediated synthesized silver nanoparticle from dried stem of Eleutherococcus senticosus in human cancer cells. Biomed Pharmacother 99:128-133

145. Castro-Aceituno V, Ahn S, Simu SY, Singh P, Mathiyalagan R, Lee HA, Yang DC (2016) Anticancer activity of silver nanoparticles from Panax ginseng fresh leaves in human cancer cells. Biomed Pharmacother 84:158-165. https://doi.org/10.1016/j.biopha.(2016).09.016

146. He Y, Du Z, Huang H, Cheng S, Wu W, Zhang K (2016) Effects of greensynthesized silver nanoparticles on lung cancer cells in vitro and grown as xenograft tumors in vivo. Int J Nanomedicine (2016): 1879-1887. https://doi. org/https://doi.org/10.2147/IJN.S103695

147. Sankar R, Maheswari R, Karthik S, Shivashangari KS, Ravikumar V (2014) Anticancer activity of Ficus religiosa engineered copper oxide nanoparticles. Mater. Sci. Eng. C 44(2014): 234-239. https://doi:https://doi.org/10.1016/j. msec.(2014).08.030

148. Wang L, Xu J, Yan Y, Liu H, Karunakaran T, Li F (2019) Green synthesis of gold nanoparticles from Scutellaria barbata and its anticancer activity in pancreatic cancer cell ( PANC-1) activity in pancreatic cancer cell ( PANC-1). Artif Cells Nanomed Biotechnol. 47 (2019): 1617-1627. https://doi.org/ https://doi.org/10.1080/21691401.(2019).1594862

149. Muller R Reuss F, Kendrovski V, Montag D (2019) Vector-borne diseases. In: Marselle M,Stadler J, Korn H, Irvine K, Bonn A. (eds) Biodiversity and health in the face of climate change. Springer, Cham (2019).

150. Dhiman RC, Pahwa S, Dhillon GPS, Dash AP (2010) Climate change and threat of vector-borne diseases in India: are we prepared?. Parasitol Res 106 (2010): 763-773. https://doi.org/https://doi.org/10.1007/s00436-010-1767-4.
151. Rajkuberan R, Prabukumar S, Sathishkumar G, Wilson A, Ravindran K, Sivaramakrishnan S (2017) Facile synthesis of silver nanoparticles using euphorbia antiquorumL. Latex extract andevaluation of their biomedical perspectives as anticancer agents. J. Saud Chem Soc 21(2017):911-919

152. Wanjala CL, Mbugi JP, Ototo E, Gesuge M, Afrane YA, Atieli HE, Zhou G, Githeko AK, Yan G (2015) Pyrethroid and DDT resistance and organophosphate susceptibility among anopheles spp. mosquitoes. Western Emerg. Infect. Dis. 21(2015):2178-2181 http://wwwnc.cdc.gov/eid/ article/21/12/15-0814_article

153. Amer A, Mehlhorn H (2006) Larvicidal effects of various essential oils against Aedes, anopheles, and Culex larvae (Diptera, Culicidae). Parasitol Res 99 (2006): 466-472. https://doi.org/https://doi.org/10.1007/s00436-006-0182-3.

154. Thiruvengadam M, Rajakumar G, Chung IM (2018) Efficacy of larvicidal activity of green synthesized titanium dioxide nanoparticles using Mangifera indica extract against blood-feeding parasites. Parasitol Res 114:171-181. https://doi.org/10.1007/s00436-014-4219-8

155. Benelli G (2015) Plant-mediated synthesis of nanoparticles: a newer and safer tool against mosquito-borne diseases. Asian Pac J Trop Biomed 6(2016):353-354. https://doi.org/10.1016/j.apjtb.(2015).10.015

156. Benelli G (2016) Plant-mediated biosynthesis of nanoparticles as an emerging tool against mosquitoes of medical and veterinary importance: a review. Parasitol Res 115(2016):23-34 https://doi.org/10. 1007/s00436-015-4800-9

157. Jiang S, Tsikolia M, Bernier UR, Bloomquist JR (2017) Mosquitocidal activity and mode of action of the isoxazoline fluralaner. Int J Environ Res Public Health. 14. https://doi.org/https://doi.org/10.3390/ijerph14020154.

158. Kalimuthu K, Panneerselvam C, Chou C, Tseng LC, Murugan K, Tsai KH, Alarfaj AA, Higuchi A, Canale A, Hwang JS, Benelli G (2017) Control of dengue and Zika virus vector Aedes aegypti using the predatory copepod Megacyclops formosanus: synergy with Hedychium coronarium-synthesized silver nanoparticles and related histological changes in targeted mosquitoes. Process Saf Environ Prot 109:82-96. https://doi.org/10.1016/j.psep.(2017).03.027

159. Sundararajan B, Kumari BR (2017) Novel synthesis of gold nanoparticles using Artemisia vulgaris L. leaf extract and their efficacy of larvicidal activity against dengue fever vector Aedes aegypti L. J Trace Elem Med Biol 43:187-196

160. Sutthanont N, Attrapadung S,Nuchprayoon S (2019) Larvicidal activity of synthesized silver nanoparticles from curcuma zedoaria essential oil against culex quinquefasciatus,Insects. 10 (2019). https://doi.org/https://doi.org/10. 3390/insects10010027.

161. Kumar D, Kumar G, Agrawal V (2017) Green synthesis of silver nanoparticles using Holarrhena antidysenterica $(L)$ wall bark extract and their larvicidal activity against dengue and filariasis vectors. Parasitol Res. 117 (2018): $377-$ 389. https://doi.org/https://doi.org/10.1007/s00436-017-5711-8.

162. Balasubramani G, Ramkumar R, Krishnaveni N, Sowmiya R, Deepak P, Arul D, Perumal P (2015) GC-MS analysis of bioactive components and synthesis of gold nanoparticle using Chloroxylon swietenia DC leaf extract and its larvicidal activity research highlights. J Photochem Photobiol B Biol 148 (2015): 1-8. https://doi.org/10.1016/j.jphotobiol.(2015).03.016.

163. Selvan SM, Anand KV, Govindaraju K, Tamilselvan S, Kumar VG (2018) Green synthesis of copper oxide nanoparticles and mosquito larvicidal activity against dengue, zika and chikungunya causing vector Aedes aegypti IET Nanobiotechnology 12 (2018): 2-8.

164. Sharon EA, Velayutham K, Ramanibai R (2018) Biosynthesis of copper nanoparticles using Artocarpus heterophyllus against dengue vector Aedes aegypti. J. Life. Sci. Scienti. Res. 4 (2018): 1872-1879. https://doi.org/https:// doi.org/10.21276/ijlssr.(2018).4.4.4.

165. Al-dhabi NA, Arasu MV (2018) Environmentally friendly green approach for the production of zinc oxide nanoparticles and their anti-fungal, ovicidal, and larvicidal properties. Nanomaterials, 8 (2018). https://doi.org/https://doi. org/10.3390/nano8070500.

166. Gandhi PR, Jayaseelan C, Mary RR, Mathivanan D, Suseem SR (2017) Acaricidal, pediculicidal and larvicidal activity of synthesized ZnO nanoparticles using Momordica charantia leaf extract against blood feeding parasites. Exp Parasitol 181 (2017): 47-56. https://doi.org/https://doi.org/10. 1016/j.exppara.(2017).07.007.

167. Murugan K, Dinesh D, Nataraj D (2017) Iron and iron oxide nanoparticles are highly toxic to Culex quinquefasciatus with little non-target effects on larvivorous fishes. Environ Sci Pollut Res 25 (2017) 10504-10514. https://doi. org/https://doi.org/10.1007/s11356-017-0313-7. 
168. Angajala G, Ramya R, Subashini R (2014) In-vitro anti-inflammatory and mosquito larvicidal efficacy of nickel nanoparticles phytofabricated from aqueous leaf extracts of Aegle marmelos Correa. Acta Trop 135 (2014): 1926. https://doi.org/https://doi.org/10.1016/j.actatropica.(2014).03.012.

169. Elango G, Roopan SM, Al-dhabi NA, Arasu V, Damodharan Kl, Elumalai K (2016) Cocos nucifera coir-mediated green synthesis of Pd NPs and its investigation against larvae and agricultural pest. Artif. Cells, Nanomedicine, Biotechnol. 45 (2016): 1581-1587. 000. https://doi.org/https://doi.org/10. 1080/21691401.(2016).1262382.

170. Sowndarya P, Ramkumar G, Shivakumar MS (2016) Green synthesis of selenium nanoparticles conjugated Clausena dentata plant leaf extract and their insecticidal potential against mosquito vectors. Artif. Cells Nanomed Biotechnol 45(2016):1490-1495. https://doi.org/10.1080/21691401.(2016).1252383

171. Jayaseelan C, Rahuman AA, Rajakumar G et al (2011) Synthesis of pediculocidal and larvicidal silver nanoparticles by leaf extract from heartleaf moonseed plant, Tinospora cordifolia Miers. Parasitol Res 109(1):185-194. https://doi.org/10.1007/s00436-010-2242-y

172. Suman TY, Ravindranath R, RS Devan Elumalai D, Kaleena PK, Ramkumar R, Perumal, P, Aranganathan L, Chitrarasu PS (2015) Larvicidal activity of titanium dioxide nanoparticles synthesized using $M$ orinda citrifolia root extract against $\mathrm{A}$ nopheles stephensi, A edes aegypti and $\mathrm{C}$ ulex quinquefasciatus and its other effect on non-target fish. Asian Pacific Journal of Tropical Disease. 5 (2015): 224-230. 10.1016/\$22221808(14)60658-7.

173. Wilkinson K, Grant WP, Green LE, Hunter S, Jeger MJ, Lowe P, Medley GF, Mills P, Phillipson J, Poppy GM, Waage J (2011) Infectious diseases of animals and plants: an interdisciplinary approach. Philos Trans R Soc B Biol Sci 366:1933-1942. https://doi.org/10.1098/rstb.(2010).0415

174. Razonable RR (2011) Antiviral drugs for viruses other than human immunodeficiency virus. Mayo Clin Proc 86(2011):1009-1026. https://doi org/10.4065/mcp.(2011).0309

175. AtanasovAG WB, Pferschy-Wenzig EM, Linder T, Wawrosch C, Uhrin P, Temml V, Wang L, Schwaiger S, Heiss EH, Rollinger JM, Schuster D, Breuss JM, Bochkov V, Mihovilovic MD, Kopp B, Bauer R, Dirsch VM, Stuppner H (2015) Discovery and resupply of pharmacologically active plant-derived natural products: a review. Biotechnol Adv 33(2015):1582-1614. https://doi. org/10.1016/j.biotechadv.(2015).08.001

176. Domingo E (2010) Mechanisms of viral emergence. Vet Res 41(2010). https://doi.org/10.1051/vetres/(2010)010

177. Smit D (2012) Anti-infective ophthalmic preparations in general practice. South African Fam. Pract. 54(2012):302-307. https://doi.org/10.1080/ 20786204.(2012).10874239

178. Galdiero S, Falanga A, Vitiello M, Cantisani M, Marra V, Galdiero M (2011) Silver nanoparticles as potential antiviral agents. Molecules. 16 (2011): 88948918. https://doi.org/10.3390/molecules16108894.

179. Haggag EG, Elshamy AM, Rabeh MA, Gabr NM, Salem M, Youssif KA, Samir A, Bin Muhsinah A, Alsayari A, Abdelmohsen UR (2019) Antiviral potential of green synthesized silver nanoparticles of lampranthus coccineus and malephora lutea. Int J Nanomedicine 14:6217-6229. https://doi.org/10.2147/ IJN.S214171

180. Desjeux $P$ (2004) Leishmaniasis: current situation and new perspectives. Comp Immunol Microbiol Infect Dis 27(2004):305-318. https://doi.org/10. 1016/j.cimid.(2004).03.004

181. Arenas R, Torres-Guerrero E, Quintanilla-Cedillo MR, Ruiz-Esmenjaud J (2017) Leishmaniasis: a review. F1000Research. 6 (2017): 1-15. https://doi.org/ https://doi.org/10.12688/f1000research.11120.1

182. Mohapatra S (2014) Drug resistance in leishmaniasis: newer developments. Trop Parasitol 4(2014). https://doi.org/10.4103/2229-5070.129142

183. Ullah I, Cosar G, Abamor ES, Bagirova M, Shinwari ZK, Allahverdiyev AM (2018) Comparative study on the antileishmanial activities of chemically and biologically synthesized silver nanoparticles (AgNPs). 3. Biotech. 8(2018):1-8. https://doi.org/10.1007/s13205-018-1121-6

184. Ahmad A, Syed F, Imran M, KhanAU TK, ZUH K, Yuan Q (2016) Phytosynthesis and Antileishmanial activity of gold nanoparticles by Maytenus Royleanus. J Food Biochem 40:420-427. https://doi.org/10.1111/jfbc.12232

185. Sumbal A, Nadeem S, Naz JS, Ali A, Mannan M, Zia M (2019) Synthesis, characterization and biological activities of monometallic and bimetallic nanoparticles using Mirabilis Jalapa leaf extract. Biotechnol Reports 22(2019)

186. Kuppusamy P, Yusoff MM, Maniam GP (2016) Biosynthesis of metallic nanoparticles using plant derivatives and their new avenues in pharmacological applications_an updated report. Saudi Pharm J 24:473484. https://doi.org/10.1016/j.jsps.(2014).11.013

187. Chung ILLMIN, Rahuman, AA, Marimuthu S, KirthiAV Anbarasan K, Padmini P, Rajakumar G (2017) Green synthesis of copper nanoparticles using Eclipta prostrata leaves extract and their antioxidant and cytotoxic activities. Nanoscale Res Lett 11 (2017): 18-24. https://doi.org/10.3892/etm.(2017).4466.

188. Balashanmugam P, Mosachristas K, Kowsalya E (2018) Kowsalya in vitro cytotoxicity and antioxidant evaluation of biogenic synthesized gold nanoparticles from Marsilea quadrifolia on lung and ovarian cancer. Int J App Pharm 10:153-158

189. Safawo T, Sandeep BV, Pola S, Tadesse A (2018) Synthesis and characterization of zinc oxide nanoparticles using tuber extract of anchote (Coccinia abyssinica (lam.) Cong.) for antimicrobial and antioxidant activity assessment. OpenNano. 3(2018):56-63. https://doi.org/10.1016/j.onano. (2018).08.001

190. Sunita P, Palaniswamy M (2017) FTIR spectral analysis and comparative antioxidant activity of chemical and biological silver nanoparticles. Int J Pharm Sci Rev Res 45:86-90

191. Ishwarya R Vaseeharan B (2016) Green Synthesized Silver Nanoparticles : Toxicity Against Poecilia reticulata Fishes and Ceriodaphnia cornuta Crustaceans. J. Clust. Sci. 28 (2016): 519-527. https://doi.org/10.1007/s10876016-1126-4.

192. Das J, Velusamy P (2013) Checking the biocompatibility of plant-derived metallic nanoparticles: molecular perspectives. Trends Biotechnol 34:440449. https://doi.org/10.1016/j.tibtech.(2016).02.005

193. Pattanayak S, Rahaman M, Maity D, Chakraborty S, Kumar S, Chattopadhyay S (2017) Butea monosperma bark extract mediated green synthesis of silver nanoparticles : characterization and biomedical applications. J Saudi Chem Soc 21:673-684. https://doi.org/10.1016/j.jscs.(2015).11.004

194. Hanan NA, Chiu HI, Ramachandran MR, Tung WH, Nadhirah N, Zain M, Yahaya N, Lim V (2018) Cytotoxicity of plant-mediated synthesis of metallic nanoparticles : a systematic review. Int J Mol Sci. 19 https://doi.org/https:// doi.org/10.3390/ijms19061725.

195. Vasquez RD, Apostol JG, de Leon JD, Mariano JD, Mirhan CMC, Pangan SS, ReyesAGM ZET (2016) Polysaccharide-mediated green synthesis of silver nanoparticles from Sargassum siliquosum J.G. Agardh: assessment of toxicity and hepatoprotective activity. OpenNano. 1(2016):16-24. https://doi.org/10. 1016/j.onano.2016.03.001

196. Rheder DT, Guilger M, Bilesky-José N, Germano-Costa T, Pasquoto-Stigliani T, Gallep TBB, Grillo R, Carvalho C, Dos S, Fraceto LF, Lima R (2018) Synthesis of biogenic silver nanoparticles using Althaea officinalis as reducing agent: evaluation of toxicity and ecotoxicity. Sci Rep 8:1-11. https://doi.org/10. 1038/s41598-018-30317-9

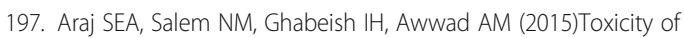
nanoparticles against Drosophila melanogaster (Diptera: Drosophilidae). J. Nanomater.. https://doi.org/10.1155/(2015)/758132.

198. Sengottaiyan A, Aravinthan A, Sudhakar C (2016) Synthesis and characterization of Solanum nigrum -mediated silver nanoparticles and its protective effect on alloxan-induced diabetic rats. J. Nanostructure Chem. 6 : 41-48. https://doi.org/10.1007/s40097-015-0178-6

199. Vasanth SB, Kurian GA (2017) Toxicity evaluation of silver nanoparticles synthesized by chemical and green route in different experimental models. Artif Cells, Nanomedicine, Biotechnol 45(2017):1720-1726. https://doi.org/10. 1080/21691401.(2017).1282500

200. Foo YY, Periasamy V, Kiew LV, Kumar GG, Malek SNA (2017) Curcuma mangga-mediated synthesis of gold nanoparticles: characterization, stability, cytotoxicity, and blood compatibility. Nanomaterials. 7 (2017). https://doi. org/10.3390/nano7060123.

201. Sengottaiyan A, Aravinthan A, Sudhakar C (2016) Nanoparticles and its impact on various organs of Sprague Dawley rats: a systematic study. Toxicol Res 5:1530-1538. https://doi.org/10.1039/c6tx00202a

202. Amin M, Hameed S, Ali A, Anwar F, Shahid S.A, Shakir I, Yaqoob A, Hasan S, Khan S. A, Rahman SU (2014) Green Synthesis of Silver Nanoparticles: Structural Features and in Vivo and in Vitro Therapeutic Effects against Helicobacter pylori Induced Gastritis. Bioinorg. Chem. Appl. (2014). https:// doi.org/https://doi.org/10.1155/(2014)/135824.

203. Mukherjee S, Sau S, Madhuri D, Bollu VS, Madhusudana K, Sreedhar B, Banerjee R, Patra CR (2016) Green synthesis and characterization of monodispersed gold nanoparticles: Toxicity study, delivery of doxorubicin and its bio-distribution in mouse model. J. Biomed. Nanotechnol. 12 (2016): 165-181. https://doi.org/https://doi.org/10.1166/jbn.(2016)2141. 
204. Alex KV, Pavai PT, Rugmini R, Prasad MS, Kamakshi K, Sekhar KC (2020) Green synthesized Ag nanoparticles for bio-sensing and Photocatalytic applications. ACS omega 5(22):13123

205. Kuppusamy P, Mashitah MY, Maniam GP, Govindan N (2014) Biosynthesized gold nanoparticle developed as a tool for detection of HCG hormone in pregnant women urine sample. Asian Pacific J Trop Dis 4(3):223-252

206. Zheng B, Qian L, Yuan H, Xiao D, Yang X, Paau MC, Choi MMF (2010) Preparation of gold nanoparticles on eggshell membrane and their biosensing application. Talanta. 82(1):177-183

\section{Publisher's Note}

Springer Nature remains neutral with regard to jurisdictional claims in published maps and institutional affiliations.

Submit your manuscript to a SpringerOpen ${ }^{\mathcal{O}}$ journal and benefit from:

- Convenient online submission

- Rigorous peer review

- Open access: articles freely available online

High visibility within the field

- Retaining the copyright to your article

Submit your next manuscript at $\boldsymbol{\nabla}$ springeropen.com 